\title{
A COMPARATIVE ANALYSIS OF OUTSTANDING CLAIM RESERVES
}

\author{
Zlata Djuric ${ }^{* 1}$ and Bojana Maracic ${ }^{2}$ \\ ${ }^{1}$ Faculty of Economics, University of Kragujevac, Kragujevac, The Republic of Serbia \\ 2 Comtrade group
}

The key processes in the business of insurance companies which define the financial viability of their business activities, as the most important element, are the adequate amount of technical reserves. A qualitative assessment of the technical reserves level is the basic support to the management of the key business processes and proper strategic and financial decision-making in order to maximize the viability, profitability, competitiveness, and further development of the company. Based on the data on the operations of an insurance company, within a single line of insurance, different, in practice, most frequently used methods were applied in order to determine the deviation amplitude of the projected amounts from the actual claims. Another direction of research focuses on actuarial practice in non-life insurance companies operating in the territory of the Republic of Serbia. The comparative analysis of the obtained projection points to the fact that the chosen methods, commonly used in actuarial practice in the Republic of Serbia, should be monitored and reviewed. The results of the multidirectional research and detection of the existing problems provide a useful framework and a stimulating mechanism, as well as the guidelines to improve the operations and better positioning of insurance in the commercial and economic environment of the Republic of Serbia.

Keywords: technical reserves, outstanding claims reserves, chain indices, loss ratio

\section{JEL Classification: G22}

\section{INTRODUCTION}

The key processes in the business of insurance companies (IC) which define the financial viability of their business activities, as the most important

* Correspondence to: Z. Djuric, Faculty of Economics, University of Kragujevac, Dj. Pucara 3, 34000 Kragujevac, The Republic of Serbia; e-mail: zdjuric@kg.ac.rs element, are the adequate amount of technical reserves (TR). The TR level enables a critical insight into the numerous aspects of the insurers industry, which can be a useful indicator for a future business strategy. Through legal regulations and international accounting standards, supervisory authorities are focused on the TR level and their mobility in order to respond to the user's requests at any time. 
The importance of an adequate TR calculation in non-life insurance has resulted in numerous studies at the European Union level: H. Müller's Report (1997), G. Manghetti's Report (2000), the KPMG Report (2002), The Report of the Working Group on the Solvency of Non-Life Insurance Companies (European Commission, 2002), who found that the TR level is the main cause of the insolvency of nonlife insurance companies, as long as there are many inconsistencies in their quantification. In addition, the existing standards do not provide a clear answer to numerous questions about the quality of the methods for assessing their quantity. "An example of a standard that leaves significant room for a wide range of accounting practices is the IFRS 4, which relates only to the general issues of the accounting treatment of insurance contracts, but does not provide solutions to all problems in this area" (Obradovic, 2014).

The issues of financial security have woven an intricate network of various mathematical, financial, statistical, even medical science contributions, including an extensive deployment of information technologies. The inherent uncertainty of the frequency, number, amount and time horizon of policyholders' claims is still the focus of many researchers. The bibliographies of numerous publications on the mentioned issues, both in the form of books, monographs and scientific papers, were compiled by K. D. Schmidt (2011).

There is a lack of research interests in non-life claim reserves in the domestic academic society. This fact has an impact on the research study published in this paper, which is defined as an analysis of the methodologies of outstanding claim reserves calculation, in the actuarial practice of non-life insurers of the Republic of Serbia (RS).

The primary goal of this paper is a comparative analysis of the results obtained by applying different methods for calculating the most reliable component of the TRs - i.e. reserves for claims incurred but not reported. As long as this technical reserves component is the most discouraged and in the focus of the research in the world actuarial authorities, the goal of the research is the possibility of applying their perceptions in the domestic, underdeveloped insurance market.
In accordance with the research purpose and goals, the general hypothesis:

$\mathrm{H}_{0}$ : The projections of the cumulative amounts of future monetary compensations should be inflationary adjusted, has been tested.

This general hypothesis has also induced an additional hypothesis:

$\mathrm{H}_{1}$ : The methodology required by the supervisory authorities should be reviewed through redesigning the current insurance legislation.

Two types of research had been requested for hypotheses testing. The general hypothesis directed one research direction, oriented towards a comparative analysis of the obtained results of the calculation of reserves for claims incurred but not reported, using the most commonly used methods in the world actuarial practice. Using the specific results of an insurance company's business, in a single line of business with a long development period (from 2006 to 2015), various methods were applied, as well as a comparative analysis of estimated claims with real claim payments in the next business year. The additional hypothesis directed the second research direction towards the methodologies used in domestic insurance companies. The questionnaire with 32 questions related to the methodologies used for calculating particular components of technical reserves was distributed in 2014 to non-life, as well as composite insurance companies operating in RS. Based on the responses received from 11 insurance companies, it was noted that the practice in claims reserves was conducted by the methodology required by the supervisor, with the lack of available staff and, hence, the necessary time for actuarial engagement on a similar research study.

Both research directions were monitored as a quantitative methodology, presented as a technical reserves calculation, as well as a qualitative methodology, through consulting relevant literature and by surveying domestic stakeholders.

This paper is structured into four thematic units. The first part is an introduction to the observed topic, 
which contains six subsections, with an overview of the most frequently used deterministic methods of claim projections, along with a review of the relevant scientific results. In the next section, such methods are applied to the paid claims of an insurance company in order to project future payments. In addition to the applied quantitative methodology, through 42 projections of both the dinar and the euro reserves for claims incurred but not reported, the qualitative research methodology was also interpreted and conducted through survey among actuaries in non-life insurance companies. In the concluding observations, the results of both directions of the survey were summarized, as a comparative analysis of the results of the projected claims and the responses in the distributed questionnaire. Identifying the key contributions and limitations of the presented research study, a set of scientific hypotheses have been specified, pointing to a future research direction.

\section{DETERMINISTIC CLAIMS RESERVING METHODS}

With a view to the potential significance of technical reserves and the impact of uncertainties on forecasts, various models have been developed, and these can be generally classified as deterministic and stochastic. Deterministic techniques provide the actuarial assessment of a potential cumulative value of the amounts of future claims paid based on the patterns in claims activities in the previous periods. However, the existing deterministic methods do not provide a concrete measure of the deviation of the obtained forecasting from possible realizations. Being aware of this shortcoming, actuaries apply different prediction models for obtaining multiple estimates of potential losses. However, no matter how wide is the range of these forecasts, questions referring to what amount may represent the optimal estimate or what is a reasonable estimate of dispersion remain open.

The determination of the optimal estimation of reserves is closely linked to absorbing the shortcomings of traditional deterministic techniques. As the Chain Ladder Method is generally the initial method in reserving, its stochastic modification has been investigated by many authors, including E. Kremer (1982), G. C. Taylor and F. R. Ashe (1983), K. D. Schmidt and A. Schnaus (1996), A. E. Renshaw and R. J. Verrall (1998), Th. Mack and G. Venter (2000), G. C. Taylor (2000), P. D. England and R. J. Verrall (2002). However, the sophistication of stochastic models requires a lot of time and other resources, so that, due to commercial imperative in terms of haste to obtain the desired forecasts as soon as possible, there is still room left for the application of stochastic models in the domain of academic research.

Deterministic methods assume that patterns in claims activities will continue to repeat in the future, which can be forecasted by observing and analyzing the past experiences in certain lines of activities. The most widely used format of displaying and analyzing data is a tabular form, where data can be systematized by: the number of claims incurred, the number of claims paid, the amount of reported claims or the amount of paid claims. Since the primary focus of an actuary, i.e. the person responsible for forecasting the amount of reserves, is on the potential payments that may occur in the next accounting period, it is recommended that a focus should be put on the analysis of the amounts of claims paid in the previous accounting periods, which may be annual, semi-annual or quarterly. Data in one table-type relate to the same year which the claim was incurred in, whereas the columns represent how many accounting periods have passed since the claim occurrence until the moment of the claim payment. Amounts in columns correspond to the same period of delay, whereas the sums paid in the same calendar year are represented along a diagonal line.

The random variable $X_{i, j}$ is the amount of the claims incurred in the year $i$ and paid within $j-1$ development years from the date on which the claim occurred. The table includes the values of the observable data, where $i+j \leq n+1$, which is why this table is also called the run-off triangle. Actuarial studies related to the losses rating and reserving use run-off triangles with individual amounts of claims paid in a given observed period $X_{i, j}$ and the cumulative losses $S_{i, j}$ incurred in the year $i$ and paid within $j-1$ development years from the date on which 
such damage occurred (Schmidt, 2006), i.e.:

$$
S_{i, j}=\sum_{k=1}^{j} X_{i, k}, \quad i=1,2, . ., n, j=1,2, \ldots, n-i+1
$$

The traditional, deterministic methods of claim reserving can be grouped into two large families: the method of chain indices and the methods based on calculating loss ratios.

\section{The Methodological Framework of Chain Indices Methodology}

Generally, all forecasting models using the chain indices method are based on the following steps: determining the chain indices, selecting the average development factor and calculating the cumulative development factors, selecting the tail-factor and obtaining projections for the claims and reserves in the next accounting period (Faculty and Institute of Actuaries, 1997).

The basic idea behind the Chain Ladder Method is that there is regularity in claims loss settlement according to the periods of delaying the settlement of claims. Hereby, the amounts of claims paid in successive development periods are compared, i.e. a rise in the percentage of cumulative payments is observed. The quotient of two adjacent amounts in the accident year represents the chain index (age-toage factor, development factor, link ratio) (Schmidt, 2006):

$$
f_{i, j}=\frac{S_{i, j+1}}{S_{i, j}}, \text { where } i=1,2, . ., n \text {, and } j=1,2, \ldots, n-i \text {. }
$$

Based on these assumptions, the amount of claims that may be reported is calculated by way of the expected value of conditional probabilities (Dahl, 2003):

$$
E\left[S_{i, j+1} \mid S_{i, 1}, S_{i, 2}, \ldots, S_{i, j}\right]=S_{i, j} \cdot r_{j}
$$

where $r_{i}$ is the selected development factor (DF) among all of the obtained factors $f_{i, j}$ for the development period $j$. If both sides of the previous equation are divided by $S_{i, j}$ it follows that:

$$
E\left[S_{i, j+1} / S_{i, j} \mid S_{i, 1}, S_{i, 2}, \ldots ., S_{i, j}\right]=r_{j}
$$

As the amounts $S_{i, j}$ and $S_{k, l}$ are independent for $i \neq j$ and $j \neq l$, the development factor $r_{j}$ does not depend on the accident year. Forecasting the amount of $S_{i, j}$ for $j \geq n-i+2$ is based on the following result, which is also mentioned by P. Dahl (2003):

Lemma 1: If $E[Z]$ is finite, then $E[Z]=E[E[Z \mid X]]$.

Starting from Assumption 3, by applying Lemma 1, we obtain:

$E\left[S_{i, j+k} \mid S_{i, 1}, S_{i, 2}, \ldots, S_{i, j}\right]=E\left[E\left[S_{i, j+k} \mid S_{i, 1}, S_{i, 2}, \ldots, S_{i, j+k-1}\right] S_{i, 1}, S_{i, 2}, \ldots, S_{i, j}\right]=$

$=E\left[S_{i, j+k-1} \cdot r_{j+k-1} \mid S_{i, 1}, S_{i, 2}, \ldots, S_{i, j}\right]=E\left[S_{i, j+k-1} \mid S_{i, 1}, S_{i, 2}, \ldots, S_{i, j}\right] \cdot r_{j+k-1}=$

$=E\left[E\left[S_{i, j+k} \mid S_{i, 1}, S_{i, 2}, \ldots, S_{i, j+k-2}\right] S_{i, 1}, S_{i, 2}, \ldots, S_{i, j}\right] \cdot r_{j+k-1}=$

$=E\left[S_{i, j+k-2} \cdot r_{j+k-2} \mid S_{i, 1}, S_{i, 2}, \ldots, S_{i, j}\right] \cdot r_{j+k-1}=E\left[S_{i, j+k-2} \mid S_{i, 1}, S_{i, 2}, \ldots, S_{i, j}\right] \cdot r_{j+k-1} \cdot r_{j+k-2}=$

$=S_{i, j} \cdot r_{j+1} \cdot r_{j+2} \cdot \ldots \cdot \cdot \cdot r_{j+k-1}$

Therefore:

$$
\begin{aligned}
& E\left[S_{i, j+k} \mid S_{i, 1}, S_{i, 2}, \ldots, S_{i, j}\right] \\
& =S_{i, j} \cdot r_{j+1} \cdot r_{j+2} \cdot \ldots \cdot \cdot r_{j+k-1}
\end{aligned}
$$

This result points to the procedure of obtaining all of the values of $S_{i, j}$ for each $j \in(n-i+2, \ldots, n)$.

The necessary reserves that the company determines are calculated as:

$$
R_{i}=E\left[S_{i, n}\right]-S_{n-i+1} \quad, i=1,2, \ldots, n
$$

Formula (5) points to the fact that the choice of the average development factor $r_{j}$, for each development period, is very important for obtaining the desired forecast. 
A run-off triangle is not complete until all the claims, at least in the oldest origin year, are paid; therefore, cost settlement for any particular year is unknown. In this respect, actuaries complete the chain indices derived from the available data in the run-off triangle, i.e. they use the remainder coefficient or the tail factor which predicts development beyond the last phase of the development for which a chain index can be calculated. Research related to determining the tail factor (TF) has resulted in numerous papers and methods; the Working Party of the American Association of Actuaries Casualty Actuarial Society - CAS (2013) presented their view in the paper "The Estimation of Loss Development Tail Factors: A Summary Report", CAS Tail Factor Working Party. The mentioned paper identifies a number of the methods grouped into 6 main classes: Bondy-Type Methods, Algebraic Methods, Benchmark-Based Methods, Curve-Fitting Methods, Methods Based on the Remaining Open Counts and Methods Based on the Peculiarities of the Remaining Open Claims.

The methods belonging to the group of Bondy-Type Methods are the most widely used in practice due to their simplicity; however, the resulting tail factor, obtained by their application, may be understated for "long-tail" lines. M. Bondy's Original Method (1960), justifies the use of the last link ratio as a predictor of future claims development (Boor, 2006), i.e. $f_{i, n+1}=$ $f_{i, n}$. As the TF is determined for each origin year, the designation $i$ can be omitted from the subscript, while each chain index is observed in the form $f_{j}=1+v(j)$, where $v(j)$ represents the development portion of the remainder coefficient. The numerous modifications of Bondy's original method have been developed. One of these assumes that the development portion of the chainindexis reduced by $50 \%$, i.e. $f_{j}+1=1+0.5 v(j)$, while alternative methods suggest that the development portion of the last index should be multiplied by two or squared, i.e. $f_{j+1}=1+2 v(j)$ or $f_{j+1}=1+v^{2}(j)$. Weller generalized the method in 1989 by using the average of the three most recent developments, whereas the Fully Generalized Bondy Method considers TF as: $f_{n}=\left(f_{n-1}\right)^{B / B-1}$, where $B$ stands for the Bondy exponent and the number ranges between 0 and 1 (CAS Tail Factor Working Party, 2013).
Algebraic methods focus on the relationships between the losses paid and incurred. Their main advantage is that they are based solely on information in the loss triangle. One of the most representative methods in this group is the Sherman-Boor Method or algorithm (Sherman \& Diss, 2005; Boor, 2006), whose application has been becoming more and more popular in actuarial practice in recent years. A possible approach to estimating TF is the assumption of the existence of the geometric relationships between the chain indices, depending on the development period until the claim is paid. The most commonly used method is the method of determining the exponential rate of "decay", which uses chain indices $f\left(d_{i}\right)$ for calculating cumulative or incremental paid losses. Here, each chain index is treated as a function of the development portion, i.e. $f\left(d_{i}\right)=1+v\left(d_{i}\right)$, assuming that the development portion $v\left(d_{i}\right)$ "decays" at a constant rate $r$, i.e. $v\left(d_{i+1}\right)=v\left(d_{i}\right) r$ (Boor, 2006). The process consists of defining the exponential curve for development portions $v\left(d_{i}\right)$. The decay constant $r$ can be estimated by using a linear trend in the values of the natural logarithm of development portions, and then the TF for the development age $d$ can be estimated as:

$$
T(d)=1+v(d) \cdot \sum_{m=1}^{\infty} r^{m} .
$$

C. L. McClenahan (1975) initiated the technique of determining the theoretical curve, assuming that incremental paid losses "decay" at a constant monthly rate $p$, but after a few months $a$, in which there were no payments. Following the exponential trend of the development periods of the chain indices and the corresponding amounts in cash, their monthly rate of decay $r$ is determined, based on which the TF is obtained by using the formula: $\left.T=\{12 \times(1-p)\} /\left\{12 \times(1-p)-p^{m-a-10} \times\left(1-p^{12}\right)\right]\right\}$.

Skurnick simplified this method (Boor, 2006) by observing the annual rate of decay in incremental payments that is proportional to the most recent payment, while for each accident year, the appropriate rate of exponential decay and the corresponding TF are calculated as: $T=\frac{1-r}{1-r-r^{y}}$, where $y$ marks the 
number of the development years which the TF will be applied to.

Determining the TF is still the focus of many researchers, because the value of $\mathrm{TF}$ significantly affects the projections of future payments to be made on claims in the following years. Due to appropriate assumptions, there is no single method that can produce accurate results; however, by testing the obtained results using different methods, one can obtain the most optimal coefficient of further developments in the payment of claims.

\section{Chain Ladder Method (CLM)}

The Chain Ladder Method is a representative method among that numerous projection methods that use chain indices. The CLM is most commonly used in actuarial practice, both by domestic and foreign ICs. P. D. England and R. J. Verrall (2002) note that the main objective of all deterministic methods is a comparative analysis of the results obtained by applying the CLM. However, J. N. Stanard (1985), P. Narayan and T. V. Warthen (1997), G. Barnett and B. Zehnwirht (2000) and G. C. Taylor (2000) focus their research on the key assumptions and examine the comparative adequacy of this method in terms of different lines of insurance.

The main characteristic of the CLM is the "original" weighting. Starting from the fact that every quotient in the column is weighted by the claim from which it originated, this method uses original weights, therefore the development factor is obtained as follows (Schmidt, 2006):

$$
r_{j}=\frac{\sum_{i=1}^{n-j+1} S_{i, j}}{\sum_{i=1}^{n-j+1} S_{i, j-1}}, j=1,2, \ldots, n-i
$$

\section{The Methods Based on the Loss Ratio Calculations}

The projections of payments to be made by an IC in future accounting periods are based on assumptions; therefore, each result obtained must be accepted with some caution. A lack of the methods based on TF is reflected in the most recent accident years because their development period to ultimate payments is very long. For this reason, the development factors derived from the past experience are relatively high and subject to numerous fluctuations, which are quite uncertain at the given moment. An alternative approach, which is relatively easy to use, is to calculate the loss ratio which indicates the share of the total claims paid (in \%) in the premiums earned by the insurer. The essence of the adequate application of the concept of a loss ratio is that premiums should correspond to the risk exposure period. Therefore, if you use the run-off triangles that contain claims given by the accident years, then the amount of the final payments is to be compared with the premiums earned (Schmidt, 2008). In the case of presenting the data according to the years of the inception of the insurance coverage, the indicative measure is a written premium. The simplest approach is to, based on the previous loss rates and earned premiums, determine the aggregate monetary amount of future payments, which, when reduced by the amount of the payments made thus far, gives the amount of necessary reserves (Saluz, Gisler \& Wüthrich, 2011). The application of this method is characterized by a greater stability of the results, especially for a small series or a new insurance line. The main shortcoming is that it relies too much on a priori information, simultaneously ignoring the payments that have already been realized.

\section{The Average Cost per Claim Method}

The Average Cost Per Claim Method assumes that the average amount of claims and their number for each development year are in a constant relation with the total number and amount of claims for the year observed. The application of this method is based on the use of the data concerning the number of the claims filed and the amount of claims incurred. This method can be applied both to paid and reported claims, where the number of such claims must correspond to the type of the amounts used. In addition, if the amounts of claims paid are 
used, they should be compared with the number of claims settled, whereas the number of reported claims should be compared to the amount of incurred claims. By dividing cumulative claim amounts by claim numbers, the amount of the average cost per reported claim is obtained. These costs are then projected to the finite amounts of individual costs in each development year by using the grossing-up factors. The same procedure is used to generate the final number of expected claims to be filed, which when applied as a multiplier to the expected average claim amount, gives the projection of the amount of the total liabilities of an IC. The necessary reserve is obtained by subtracting the obtained amount in respect of the amount of claims paid.

This projection can be very useful, because the analysis of the experience with respect to the amount and number of claims makes it possible to review the trends in the filing of damages and their liquidation, as well as the average amount of claims. The method itself can provide satisfactory answers, especially in the case of organizational or external fluctuations; it can also help in the detection of the adequacy of other actuarial projection techniques. It can be applied to the data aggregated by the year of origin, the accident, the respective year of inception or the calendar year. Although this method can be applied to all lines of insurance, it is most commonly used regarding the "long tail" lines.

\section{The Bornhuetter-Ferguson (BF) Method}

Bornhuetter-Ferguson's method combines the Average Cost Per Claim with the Chain Indices Method. The initial, realistic assumption is that the total loss for each year of operation can be divided into the respective past and future portions that are subjected to a separate analysis. The first part of the evaluation, which relates to the claim payments made, is known or adequately evaluated, taking into account the reserves for incurred but not reported claims. Uncertainties contained in future payments to be made will not be estimated by applying the same pattern of historical payment realizations; they will be estimated by using a more general estimator, based on the loss ratio for a given line of insurance. By summing up the two estimates, a more sensitive assessment of the possible final payments and therefore the necessary reserves is obtained.

If we analyze the amounts of cumulative payments, $S_{i, i^{\prime}}$ which are actually the variables that are independent of the year of origin $i$, the assumption of the BF method is that there are the parameters $\alpha_{1^{\prime}} \alpha_{2^{\prime}, \cdots}$ $\alpha_{n}$ and the rates $\beta_{1^{\prime}}, \beta_{2^{\prime} . . .} \beta_{n^{\prime}}$ where $\beta_{n}=1$ (because the development for the first year of origin is concluded), which are used for projecting the future and past portions of the aggregate payments, therefore (Mack, 2006), $\forall i: 1 \leq i \leq n, \quad \forall j: 1 \leq j \leq n-1$ :

$$
\begin{aligned}
& E\left[S_{i, 1}\right]=\alpha_{i} \cdot \beta_{1}, \text { and } \\
& E\left[S_{i, j+k} \mid S_{i, 1}, S_{i, 2}, \ldots, S_{i, j}\right]=S_{i, j}+\left(\beta_{j+k}-\beta_{j}\right) \cdot \alpha_{i}
\end{aligned}
$$

Since $S_{i, j}$ represent cumulative amounts, thus $\alpha_{\mathrm{j}}$ is a cumulative TF. According to (8), it follows:

$$
E\left[S_{i, j}\right]=\alpha_{i} \cdot \beta_{j} \text { and } E\left[S_{i, n}\right]=\alpha_{i} .
$$

Starting from the relation $\forall i: 1 \leq i \leq n, \quad \forall j: 1 \leq j \leq n-i+1$, we obtain: $E\left[S_{i, n} \mid S_{i, 1}, S_{i, 2}, \ldots, S_{i, j}\right]=S_{i, j}+E\left[S_{i, n}-S_{i, n-i+1}\right]$,

this, according to the basic assumptions, implies the following:

$$
\begin{aligned}
& E\left[S_{i, n} \mid S_{i, 1}, S_{i, 2}, \ldots, S_{i, j}\right]= \\
= & S_{i, j}+\left(\beta_{n}-\beta_{n-i}\right) \cdot \alpha_{i}= \\
= & S_{i, j}+\left(1-\beta_{n-i+1}\right) \cdot \alpha_{i}
\end{aligned}
$$

The BF projection is written as (Schmidt, 2008):

$$
E\left[S_{i, n}\right]=S_{i, n-i+1}+\left(1-\beta_{n-i+1}\right) \cdot \alpha_{i}
$$

where $\beta_{n-i+1}$ is an a posteriori estimation and $\alpha_{i}$ is an $a$ priori estimation of ultimate losses. 
As the CLM assumes that:

$$
E\left[S_{i, n} \mid S_{i, 1}, S_{i, 2}, \ldots, S_{i, j}\right]=E\left[S_{i, j}\right] \cdot \prod_{k=j+1}^{n-1} r_{k}=E\left[S_{i, 1}\right] \cdot \prod_{k=1}^{n-1} r_{k},
$$

We obtain: $E\left[S_{i, j}\right]=E\left[S_{i, n}\right] \cdot \prod_{k=0}^{n-1} r^{-1}$.

If this result is compared with (9), it is evident that:

$$
\beta_{j}=\prod_{k=j+1}^{n-1} r_{k}^{-1}
$$

Thus, (11) is now written as:

$$
E\left[S_{i, n}\right]=S_{i, n-i+1}+\left(1-\frac{1}{\prod_{k=n-i+1}^{n-1} r_{k}}\right) \cdot \alpha_{i}
$$

This relation points to a significant difference between the BF method and the CLM - the method of choosing estimators. For the CLM, we have (Schmidt, 2008):

$$
\begin{aligned}
& E\left[S_{i, n}\right]=S_{n-i+1} \cdot \prod_{k=n-i+1}^{n-1} r_{k}= \\
& =S_{n-i+1}+S_{n-i+1} \cdot\left(\prod_{k=n-i+1}^{n-1} r_{k}-1\right)= \\
& =S_{n-i+1}+\frac{E\left[S_{i, n}\right]}{\prod_{k=n-i+1}^{n-1} r_{k}} \cdot\left(\prod_{k=n-i+1}^{n-1} r_{k}-1\right)
\end{aligned}
$$

therefore:

$$
E\left[S_{i, n}\right]=S_{n-i+1}+\left(1-\frac{1}{\prod_{k=n-i+1}^{n-1} r_{k}}\right) \cdot E\left[S_{i, n}\right]
$$

The difference between (13) and (14) is only in the last member of the estimation: in the CLM, it is obtained from observable data, whereas the BF method allows $\alpha_{i}$ to be any estimator of the ultimate loss development. Therefore, the parameter $\alpha_{i}$ is an a priori exogenous factor, obtained by some other professional expertise. The application of the BF method is mainly based on the loss ratio, i.e. on the ratio of incurred claims to earned premiums as the $\alpha_{i}$ predictors of ultimate losses. Since the loss ratio indicates the historical experience of the IC activities regarding the share of claims (in \%) in premiums, this product indicates the likely amount of the expected losses in the next business year. In terms of the CLM, the inverse product of the development factors indicates the percentage of the paid claims in the expected aggregate payment for a given development year, therefore $1-1 / \prod_{k=n-i+1}^{n-1} r_{k}$ represents the amount (in \%) of expected unpaid claims. If the projection of possible losses per development years is calculated using the ratio of claims to premiums, by multiplying this amount and the factor: $1-1 / \prod_{k=n-i+1}^{n-1} r_{k}$, we obtain the amount of the necessary reserve (Schmidt, 2008).

In contrast to the method of the expected losses, where projection ignores the actual realization of payments, and the method of chain indices, where full credibility is given to paid claims, the BF method relies on data from the past, but not as the only benchmark for the evaluation of future payments. Concerning the development of losses, the credibility of projections is based on the claims development in most recent experience periods; therefore, the weighting factor of the initial realizations declines (Martínez-Miranda, Nielsen \& Verrall, 2013). Incurred but not reported claims will be developed in the future based on the expected payments; incurred payments are not the predictors of a future development; therefore, payment fluctuations in the early stages do not impair the projection of the necessary reserves. This is actually the main argument for the implementation of the BF method for "long-tail" insurance lines, as well as in the case of other insurance lines characterized by significant fluctuations in the realization of incurred payments. 


\section{Stanard-Bühlmann Method}

This method, also known as the Cape-Code (CC) Method, was independently developed by J. N. Stanard (1985) and H. Bühlmann (1983), as an improved variation of the BF method. The initial assumption concerning the division of ultimate claims to reported and incurred but not reported claims is retained, as well as the sensitivity of determining the loss ratio. In contrast to the BF method, where the loss ratio is estimated by the person liable for calculating reserves, the CC method determines the expected loss ratio based on the historical experience of the total amounts of reported claims. For each development year, the loss ratio is calculated based on the total reported claims and earned premiums, whereas the expected loss rate for the next development period represents the weighted average of all ratios obtained. Since the expected claims are based on the reported losses, a sufficient volume of data is required, which often limits the application of this method. "A lack of quality data is a critical factor, because with inadequate data no results will be produced, no matter how perfect the model may have been" (Kočović, Mitrašević, Kočović i Jovović, 2011, 2011).

\section{The Methodology for Calculating Claim Reserves Prescribed by the National Bank of Serbia (NBS)}

The Insurance Law of the Republic of Serbia, i.e. the Decision on the Detailed Criteria and the Manner of Calculating Claim Reserves, allows the application of actuarial methods for the calculation of incurred but not reported claim reserves; it also allows to calculate reserves based on the data on resolved and reserved incurred reported but not settled claims without the involvement of annuity claims. Also, the calculation should not include any costs associated with the settlement and payment of claims. According to this principle, the amount of reserves for incurred but not reported claims concerning the self-insured retention of the company for the particular insurance line represents the sum of settled and unsettled reported claims in retention within a certain insurance line, corrected by the coefficient for the calculation of claims incurred but not reported, i.e..

$$
R_{t}^{I B N R}=a_{t} \cdot\left(S_{t}+R_{t}\right)
$$

where $S_{t}$ stands for the amount of settled (not including annuity) claims in retention in a particular insurance line, $R_{t}$ is the amount outstanding (excluding annuities) incurred reported but unsettled claims in retention in the particular insurance line, $a_{t}$ the coefficient for the calculation of incurred but not reported claims and $R_{t}^{I B N R}$ resulting amount of incurred but not reported claims in the observed insurance line (Službeni glasnik RS, 2007).

The correction coefficient $a_{t}$ is calculated on $31^{\text {st }}$ December of the current year for those lines of insurance that have been conducting particular insurance activities for more than three years (or at least two years) and the same cannot be smaller than 0.1. It represents the arithmetic mean of the coefficients $k_{i}$ calculated for the current and previous two insurance years. The coefficient $k_{i}$ for each of the last three or two years is the quotient of: 1) the sum of the amounts of the claims settled during the year and the outstanding incurred reported claims on $31^{\text {st }}$ December that have occurred in the previous period and are the first reported in the year for which this coefficient is determined and 2) the sum of the amounts of the claims settled during the year and the outstanding incurred reported claims on $31^{\text {st }}$ December of the year for which this coefficient is determined. If insurance activities in a particular insurance line last for less than 2 years, the value of this coefficient is 0.1 .

If the incurred claims reserve is calculated by applying some other method, its amount cannot be smaller than the amount obtained by using the above-described method; furthermore, the reserve calculated according to the method presented above must not be smaller than the reserve calculated at the end of the previous year. 


\section{METHODOLOGY AND RESEARCH RESULTS}

Stanard \& Poor's (S \& P), one of America's leading financial services companies, calculates the level of TR by applying a comparative analysis of the results obtained by using the following three methodologies: the paid loss development method, the incurred loss development method, and the BF methods. According to their analysis, the triangulation techniques based on paid and incurred losses produce the most appropriate results when using the five-year weighted average of DF that best reflect the balance between stability and reliability in developing factors (Standard \& Poor's Ratings Services, 2008).

The results of the research carried out by the global network of consulting and audit firms - KPMG at the EU level (2002) - show that a comparative analysis of the reserving results obtained by means of various actuarial methods is the generally accepted way to minimize the deviations of proposed projections from the actual realization of payments. In almost all European countries, the methods based on the run-off triangles proved to be the most effective and in terms of cumulative paid claims in the previous business years the CLM was the method most commonly used. Beside the mentioned method, one of the following methods is also simultaneously used: the Loss Ratio Method, the Average Cost per Claim Method or Bornhuetter-Ferguson's method. In Spain, it is even prescribed by the law that at least two methods must be used when determining reserves; furthermore, the selected methods must include data for at least five preceding years.

All of the mentioned studies have initiated research in the applied practices in non-life ICs operating in Serbia's economic environment. According to the results of the survey which was carried out on 11 nonlife insurance companies (2 of which are in private and the remaining 9 in foreign ownership), the actuaries follow the Decision on the Detailed Criteria and the Manner of Calculating Claim Reserves (NBS) and the CLM when projecting the uncertain amounts of future claim reserves. Hence, the focus of this research is directed towards the application of various deterministic methods in order to determine whether their choice is the most appropriate or whether some other method provides better results closer to payment realizations in 2016.

In the line of business with a long development period, the claim payment data of an insurance company were used in this research. The projections of the potential amounts of future payments were done by using the triangulation methods applying the development triangles for paid and incurred losses in the period from 2006 to 2015 in order to make it possible to compare the results with the realizations of these amounts in 2016. Additionally, all the projections obtained by using the run-off triangles, the BF and the CC methods calculated amounts in dinars (RSD) and euros, respectively. Currency conversion was done at the official exchange rate applicable on $31^{\text {st }}$ December.

Loss development triangles are formed based on the cumulative amount of payments as per accident year and payment delay periods of 12 to 120 months. For each development year, the chain indices were selected and obtained as follows: 1) conservative mean-value, i.e. the selection of the highest chain index value in the observed development period; 2 ) the arithmetic mean of all the chain indices as per columns for each year of claims development; 3) the arithmetic mean of the last three chain indices in each column; 4) the arithmetic mean of the last five chain indices in each column; 5) the median of the indices, i.e. the arithmetic mean of the indices that remains after eliminating the highest and the lowest index values in each column; 6) the geometric mean obtained by applying GEOMEAN, a function contained in the Microsoft Office Excel 2007 software, i.e. as $\sqrt[n-1]{f_{1} \cdot f_{2} \cdot \ldots f_{n}}$, where $f_{1^{\prime}} f_{2^{\prime}, \ldots, f_{n}}$ are chain indices, and 7) the weighting means obtained by using CL weights.

Among the many techniques used for determining the tail factors, the following methods were used: Bondy's method, which carries out the selection based on the last calculated chain index for the year that has the longest claims development period and the two more modifications of this method, where the development portion of the last chain index is squared or doubled, 
respectfully; Sherman-Boor's method; Method of Exponential Approximation; McClenahan's method and Scurnick's method.

The tail factors were determined for each of the seven mentioned ways of obtaining the development factor by using all the seven methods and the projection of future payments for incurred but not unreported claims was done for the development period from 2006 to 2015. So, 49 projections were obtained only for the chain-ladder based methods. The results of the projections were compared with the real payments in 2016, for all the claims that occurred from 2006 to 2015 , but which had not been reported in that period. In the chain-ladder based methods, the amount the closest to the actual payments was the method where the development factors were obtained over a medial average, with the tail factor determined by using the Bondy method. In addition to the chain index methods, the amount of these potential payments by the expected cost method, the BF and the CC methods was obtained. The results of the projected incurred but not reported claims in the EUR currency are given in Table 1, while the same results in the RSD currency are accounted for in Table 2.

Table 1 The comparative analysis of the projection methods (in EUR)

\begin{tabular}{l|l}
\hline Method & $\begin{array}{l}\text { Projected amount of } \\
\text { reserves for claims }\end{array}$ \\
\hline Chain Index Method & 12312428 \\
Average Cost per Claim Method & 13141133 \\
CL Method with Bondy ROC & 12356404 \\
Bornhutter-Ferguson Method & 12359573 \\
CapeCod Method & 12232147 \\
\hline
\end{tabular}

Realization in 2016: 11728866

Source: Authors
Table 2 The comparative analysis of the projection methods (in RSD)

\begin{tabular}{l|l}
\hline Method & $\begin{array}{l}\text { Projected amount of } \\
\text { reserves for claims }\end{array}$ \\
\hline Chain Index Method & 1578908008 \\
Average Cost per Claim Method & 1527416691 \\
CL Method with BondyROC & 1623425309 \\
Bornhutter-Ferguson Method & 1659685804 \\
Cape Cod Method & 3058845966 \\
NBS Methodology & 1892155950 \\
\hline \multicolumn{2}{c}{ Realization in 2016: 1344383096 } \\
\hline
\end{tabular}

Source: Authors

The second direction of the research is focused on actuarial practice in the non-living ICs operating in the territory of the RS. The questionnaire containing 32 questions, focused on the calculation of the individual components of technical reserves, was distributed to the insurance companies only engaged in non-life insurance and composite insurance companies in order to detect divergence in the applied methodology.

The following questions were posed in the mentioned questionnaire: 1. Which line of non-business is presented in your insurance company's portfolio? 2. Are technical reserves calculated by a qualified actuary? 3. How many years of experience does the person responsible for technical reserves calculations have? 4 . What percentage of the working hours during the year does this person spend on TR calculations? 5. Which types of TRs are calculated? 6. Unearned premium reserves are calculated by using: a) the pro-rata temporis method; b) the $1 / 24$ method; c) the quarterly method; d) the same-rate method; 7. Please, explain how you use the method selected that was used in the previous question. 8. Which method is used for an RBNS estimation: a) the estimation of each separate claim; b) the average method; c) by using 
tables; c) the claim ratio method? 9. Please, explain how you use the method selected that was used in the previous question. 10. Which method is used for an IBNR estimation: a) the flat methods based on paid and RBNS claims; b) the claim ratio; c) the chain ladder; d) by using another method (specify which)? 11. Please, explain how you use the method selected that used in the previous question. 12. If you use the chain ladder method, then explain the methodology used for the calculation of development factors. 13. How many development years are presented in the claim triangles? 14. Do you calculate the tail factor and how? 15. Which data are presented in the claim triangles: a) paid claims; b) paid claims including costs; c) the sum of paid claims and RBNS? 16. Which data are presented in the claim triangles: a) the occurred claims; b) the reported claims; c) the paid claims? 17: Do you think that the expected inflation should be used in calculations? 18. Are the claims paid by the reinsurer included in the claim triangles? 19. How much is the average deviation of the projected reserves and the real paid claims? 20. Do you calculate the adequacy of the projected reserves? 21. How do you calculate adequacy? 22. Which method is used for claim costs reservation: a) the method of the claim costs ratio; b) by using another method? 23. Please, explain how you use the method selected that had been used in the previous question. 24. Do you use statistical methods for TR projections? 25. Specify which statistical methods you have used and how useful their application has proved to be? 26. Would you like to use statistical methods and how frequently? 27. Which method is used for premium rates calculations: a) the class method, b) the method of premium rate estimations, c) experientially, d) by using another method (specify which)? 28. Please, explain your using of the method selected that had been used in the previous question. 29. Are premium rates corrected, how often and in what manner? 30. Which percentage of technical premiums are variable costs? 31. Which percentage of gross premiums is a reinstatement? 32. Do you have any suggestion about the calculation of technical reserves?

The distributed questionnaire was completed by 11 ICs, of which the 2 domestic ones solely engaged in non-life insurance, and 9 foreign companies, of which the 7 companies only offer non-life insurance, whereas the 2 companies offer both non-life and life insurance.

In $81.82 \%$ of the surveyed ICs, the authorized actuaries are liable for calculating reserves; however, in $45.45 \%$ of these companies, the actuaries have less than 5 years of experience in the field of reserving. The actuaries employed in domestic ICs have over 6 years of work experience; yet about $10 \%$ of their working day is spent on calculating reserves, which is inadequate concerning the contribution that due to their experience and practice can be provided in terms of the development and amendments of the existing laws and regulations in this field. The situation in other ICs differs from one IC to another - their actuaries spend from 5\% to as much as 50\% of the working time on the calculation of reserves; the work experience of their actuaries varies from 3 to 6 years in terms of reserving tasks. The methodology applied by the employees regarding the valuation of certain components of the reserves is in line with the regulations prescribed by the National Bank of Serbia. Reserves for incurred but not reported claims until the end of the accounting period are determined by the actuaries in several ways: $88.89 \%$ of the actuaries follow the Decision of the NBS and its prescribed methodology, 33.33\% apply the Expected Loss Method and $77.78 \%$ apply the Chain Ladder Method (CLM). The actuaries employed in domestic ICs apply the NBS methodology and the CLM when calculating reserves. They also apply different methods for the selection of the development factors: three actuaries use weighted averages, two use median values, whereas one actuary (employed in a domestic IC) uses both methods plus the arithmetic factors for the last three accident years.

The question: "Do you enter the liabilities borne by the reinsurer in the run-off triangles?" divided the insurers, both the foreign and the domestic ones; 5 actuaries do not register the amounts handled by reinsurers, whereas 4 insurance companies, quite unjustifiably, use these amounts when calculating the amounts of claims paid. The transfer of risks underwritten to a reinsurance company eases the insurers' liabilities in terms of future payments and 
their responsibilities concerning the payment of such claims. These different approaches concerning the data entered in the run-off triangles make a great difference in practice when quantifying the amounts of reserves. The use of reinsured amounts in the runoff triangles is by all means unjustifiable and should be restricted by law, since such practice is motivated by the wrongful obtaining of tax reliefs. Until the Solvency II Directive, which prohibits the use of these amounts in the projections of future cash flows, comes into force in Serbia, it is necessary that the NBS and its auditors and supervisors who monitor the activities of ICs should react and regulate these matters.

All the actuaries position the amounts in the runoff triangles according to the accident year and the development year; however $28.57 \%$ of the surveyed actuaries also enter the amounts payable by reinsurers. However, divergence is present in practice both with the foreign and the domestic insurers. When asked about the statistical methods they apply in terms of reserving, one actuary employed in a domestic IC answered that he applied the methods of correlation analysis, standard deviations and other methods, while the other actuaries do not apply statistical methods, but are willing to include statistical and stochastic projection methods. The encouraging fact is that the intellectual potentials of the hired actuaries strive towards the scientific soundness of the methods they use, which should be more than enough reason for competent internal and external bodies to mobilize their energy and efforts and provide continuous training opportunities in order to achieve the greater preparedness of our insurance market for harmonization with the complex new regulations implemented in the European Union.

Quantifying the costs of settling, reserving, estimating and liquidating claims in an unstable business environment faced with an increasing unfair competition in the race to win over new customers is not an easy task to do. An insight into the balance sheets and the income statements of the non-life insurance companies operating in the RS confirms the necessity to introduce more reliable methods and be more cautious when projecting the amounts of reserves. The reports on the audit of these companies, i.e. the auditor's opinion, also confirm our conclusion. At the end of 2013, while supervising the operation of the ICs and analyzing the individual items from their balance sheets, the auditors found that five insurers (AS Insurance, DDOR Novi Sad, Millennium Insurance, Sava Insurance and Triglav Insurance) had inadequate reserves. In the aforementioned ICs, the costs of insurance in the individual insurance lines significantly exceed the expense loading (the balance sheets, the income statements and the auditor's opinion are available on the website of the NBS for all the ICs operating in the territory of the RS). However, according to the information provided in the completed questionnaires, 10 actuaries calculate these costs according to the Decision on the Detailed Criteria and the Manner of Calculating Claim Reserves (NBS).

\section{CONCLUSION}

Inherent uncertainty with respect to both the occurrence and the amount of claims in non-life insurance reflects most on the projection of the amounts of technical reserves. Numerous scientific papers and studies are directed towards obtaining the best assessments of their amounts. However, there have almost been no empirical research studies regarding the topic in national academic/actuarial papers. This fact gives special relevance to this paper, which consists of the two directions of the empirical analysis.

- The results of the quantitative analysis, conducted in the previous section of the paper, imply the following conclusions:

- The calculations based on the loss triangles in the euro amounts indicate that in the methods based on the chain indices, the slightest deviation of the projection from the claims paid in 2016 is caused by implementing the development factors obtained via median value, with the remainder coefficient according to Bondy's method;

- The comparative analysis of the obtained projection of the euro amounts regarding the claims incurred but not reported indicates that 
the most appropriate forecasting of payments in the following year is obtained by using the CC method, where the deviation from the actual realization is $4.29 \%$, whereas the Average Cost per Claim Method provides the over-reserving of $12.04 \%$. Bondy's method with its median value - as the best projection method concerning the triangulation methods - deviated about 5\% from the actual realization of the incurred loss payments.

In the projections of the reserves conducted in the RSD amounts, the Cost per Claim Method produces the slightest deviation $(+13.615 \%)$ from the incurred losses paid in 2016, whereas the projection performed by applying the Decision of the NBS has resulted in the over-reserving of $40.745 \%$ on the account of claims incurred but not reported.

In terms of non-life ICs, the realization of the loss payments is the highest in the first year of insurance coverage; in many other lines of insurance, insurance coverage is short-term. So far, these arguments have been sufficient for the regulators monitoring the activities of the ICs operating in the EU territory; therefore they do not insist on inflation-adjusted projections. The instability of market conditions, as well as a high inflation, present in the Republic of Serbia as well as in other developing countries, point to the need for the implementation of adjustments for inflation when projecting future payments to be made on claims. The projection of the amount of the technical reserves in the selected insurance company for one insurance line, as well as a comparative analysis of the obtained results, indicate that the application of the deflated data results in minor deviations between the expected and the realized payments. The best method of projecting amounts in RSD resulted in the over-reserving of $13 \%$, whereas the projections in the euro amounts differ about $5 \%$ from such realizations, which confirms the basic hypothesis and points to the fact that inflation should not be neglected even in the short-term lines of insurance.

By analyzing the responses to the questions from the distributed survey, what was observed was an insufficient number of the actuaries hired to calculate the technical reserves amounts since their practical perception can be the best ground for the further monitoring of the given topic. The suggestions regarding the current situation and the directions of correcting the technical reserves calculation, accompanying the responses to the questions in the survey, indicate a detected lack of current regulations and a necessity for passing a detailed rulebook and the best possible model of calculating TRs, followed by mitigating the excessive rigidity of local regulations with respect to reserving incurred claims.

The comparative analysis of both directions of the research study has confirmed the additional hypothesis since the best methods detected in the quantitative research were not used in the actuaries' practice in the Republic of Serbia. The practitioners' perceptions and suggestions of the current situation and the directions concerning the correction of the calculation of technical reserves point to the insufficiency of the existing regulations and the necessity for establishing more detailed regulations and a better model for the calculation of TRs, including the mitigation of excessively rigid local regulations applicable to claim reserving.

An undeniable quality of the paper is reflected in the presentation of the numerous methods used to calculate reserves with respect to claims incurred but not reported, as well as the implementation of the various methods used for determining the remainder coefficient since the conducted research study has proved to have a significant effect on the amount of projected reserves.

Being aware of the fact that all the projections were made based only on a single line of business operation of an insurance company, the authors believe that the obtained results provide both the base and the incentive for similar empirical research studies. Simultaneously, this suggests the possible directions of further researching efforts. The intention to use the concrete, historical operating results to analyze the adequacy of the applied techniques in all nonlife insurers could not have been realized due to the protection and confidentiality of their data. 


\section{REFERENCES}

Barnett, G., \& Zehnwirth, B. (2000). Best estimates for reserves. Proceedings of the Casualty Actuarial Society, 87(167), Part 2, 245-321.

Boor, J. (2006). Estimating tail development factors: What to do when the triangle runs out. Casualty Actuarial Society Forum, Winter, 345-390.

Bühlmann, H. (1983). Estimation of IBNR reserves by the methods chain ladder, cape cod and complimentary loss ratio. International Summer School. Unpublished.

Casualty Actuarial Society (CAS). (2013). The estimation of loss development tail factors: A summary report. Tail Factor Working Party.

Dahl, P. (2003). Introduction to Reserving. Retrieved November 10, 2017, from http://kurser.math.su.se/ pluginfile.php/5901/course/section/1369/dahl2011.pdf

England, P. D., \& Verrall, R. J. (2002). Stochastic Claims Reserving in General Insurance. British Actuarial Journal 8(3), 443-518. doi.org/10.1017/S1357321700003809

European Commission. (2002). Report of the working group on non-life technical provisions to the IC Solvency Subcommittee. Working paper, MARKT/2529/02. Retrieved November 10, 2017, from http://europa.eu.int/ comm/internal_market/insurance/solvency_en.htm

Faculty and Institute of Actuaries. (1997). Claims Reserving Manual. The Faculty and Institute of Acturies.

Kočović, J., Mitrašević, M., Kočović, M. i Jovović, M. (2011). Problemi alokacije kapitala kompanija za neživotno osiguranje. Ekonomski horizonti, 13(2), 45-69.

KPMG. European Commission. (2002). Study into the methodologies to assess the overall financial position of an insurance undertaking from the perspective of prudential supervision.

Kremer, E. (1982). Credibility theory for some evolutionary models. Scandinavian Actuarial Journal, 3-4, 129-142. doi. org/10.1080/03461238.1982.10405260

Mack, Th. (2006). Parameter estimation for Bornhuetter/ Ferguson. Casualty Actuarial Society Forum, Fall 2006, 141157.
Mack, Th. (2008). The prediction error of Bornhuetter/ Ferguson. ASTIN Bulletin: The Journal of the IAA, 38(1), 87-103. doi.org/10.1017/S0515036100015075

Mack, Th., \& Venter, G. (2000). A Comparation of stochastic models thah reproduce chain ladder reserve estimates. Insurance: Mathematics and Economics, 26(1), 101-107. doi. org/10.1016/S0167-6687(99)00039-6

Manghetti, G. (2000). Report: Technical provisions in nonlife insurance. Paper presented at the conference of the Insurance Supervisory Authorities of the Member States of the European Union.

Martinez-Miranda, M. D., Nielsen, J. P., \& Verrall, R. (2013). Double chain ladder and Bornhuetter-Ferguson. North American Actuarial Journal, 17(2), 101-113. doi.org/10.1080 /10920277.2013.793158

McClenahan, C. L. (1975). A Mathematical Model for Loss Reserve Analysis. Proceedings of the Casualty Actuarial Society, 62, 134-153.

Müller, H. (1997). Report: Solvency of insurance undertakings. Paper presented at the conference of the Insurance Supervisory Authorities of the Member States of the European Union.

Narayan, P., \& Warthen, T. V. (1997). A comparative study of the performance of loss reserving methods through simulation. Casualty Actuarial Society Forum, Summer 1997, vol 1, 175-196.

Obradovic, V. (2014). Inconsistent application of international financial reporting standards. Economic horizons, 16(3), 231-243, doi: 10.5937/ekonhor14032390

Renshaw, A. E., \& Verrall, R. J. (1998). A stochastic model underlying the chain-ladder technique. British Actuarial Journal, 4(4), 903-923. doi.org/10.1017/S1357321700000222

Saluz, A., Gisler, A., \& Wüthrich, M. (2011). Development pattern and prediction error for the stochastic bornhuetter-ferguson claims reserving method. ASTIN Bulletin: The Journal of the IAA, 41(2), 279-313. doi:10.2143/ AST.41.2.2136979

Schmidt, K. D. (2006). Methods and Models of Loss Reserving Based on Run-off Triangles: A Unifying Survey. Casualty Actuarial Society Forum, Fall 2006, 269-317. 
Schmidt, K. D. (2008, July 14-16). Bornhuetter-Ferguson as a general principle of loss reserving. Paper presented at the ASTIN Conference, Manchester.

Schmidt, K. D. (2011). A bibliography on loss reserving. Technische Universität Dresden.

Schmidt, K. D., \& Schnaus, A. (1996). An extension of Mack's model for the chain-ladder method. ASTIN Bulletin: The Journal of the IAA, 26(2), 247-262. doi.org/10.2143/ AST.26.2.563223

Sherman, R. E., \& Diss, G. (2005). Estimating the Workers Compensation Tail. Casualty Actuarial Society Forum, Fall 2004.

Stanard, J. N. (1985). A simulation test of prediction errors of loss reserve estimation tehniqes. Proceedings of the Casualty Actuarial Society, 72, 124-153.
Standard \& Poor's Ratings Services. (2008). Property/ Casualty Insurance Criteria For Assessing Loss Reserve Adequacy For U. S. Based Insurers/Reinsurers. Retrieved November 11, 2014, from www.ratingsdirect.com

Taylor, G. C., \& Ashe, F. R. (1983). Second moments of estimates of outstanding claims. Journal of Econometrics, 23(1), 37-61. doi:10.1016/0304-4076(83)90074-X

Taylor, G. C. (2000). Loss Reserving: An Actuarial Perspective. New York, NY: Springer, doi:10.1007/978-1-4615-4583-5

Službeni glasnik RS. (2007a). Odluka o bližim kriterijumima $i$ načinu obračunavanja rezervisanih šteta. Beograd, Republika Srbija: Službeni glasnik RS, br. 86/2007.

Zlata Djuric is an Assistant professor at the Faculty of Economics at the University of Kragujevac, the Republic of Serbia. She teaches the subjects of Insurance and Financial, and Actuarial Mathematics. She received her PhD at the Faculty of Economics of the University of Kragujevac. Her scientific interest is the application of mathematics in the field of finance and insurance.

Bojana Maracic is engaged as the Product Owner in Paysafe Group on behalf of Comtrade and also as the appointed actuary in Sogaz Serbia. She has engaged in insurance business. 


\title{
KOMPARATIVNA ANALIZA REZERVACIJE ŠTETA
}

\author{
Zlata Đurić*1 i Bojana Maračić \\ ${ }^{1}$ Ekonomski fakultet Univerziteta u Kragujevcu \\ 2 Comtrade group
}

Ključni procesi u poslovanju osiguravajućih društava, kojima se definiše finansijski bonitet nijhovih poslovnih aktivnosti, kao najznačajniji element ističu adekvatan iznos tehničkih rezervi. Kvalitetna procena visine tehničkih rezervi predstavlja katalizator za brojne funkcionalne procese, koji kao krajni cilj imaju maksimiziranje profitabilnosti, konkurentnost i dalji razvoj, kroz širenje postojećih i uvođenje novih linija poslovanja. U radu su na podacima poslovanja jednog osiguravajućeg društva, u jednoj liniji osiguranja, primenjene različite, u praksi najčešće korišćene metode njihove procene, $u$ cilju utvrđivanja razmera odstupanja projektovanih iznosa od stvarne realizacije šteta. Drugi pravac istraživanja, usmeren je na aktuarsku praksu neživotnih osiguravajućih društava koja posluju u Republici Srbiji, u cilju otkrivanja divergencije u primenjenoj metodologiji. Komparativna analiza dobijenih projekcija ukazuje na činjenicu da izabrane metode, najčešće korišćene u aktuarskoj praksi Republike Srbije, treba pratiti i preispitati. Rezultati višesmernog istraživanja i identifikovanja postojećih problema, daju koristan okvir i mehanizme podsticaja, kao i smernice za unapređivanje poslovanja i bolje pozicioniranje osiguranja u ekonomski ambijent Republike Srbije.

Ključne reči: tehničke rezerve, rezerve za štete, lančani indeksi, stopa šteta

\section{JEL Classification: G22}

\section{UVOD}

Ključni procesi u poslovanju osiguravajućih društava (OD), kojima se definiše finansijski bonitet njihovih poslovnih aktivnosti, kao najznačajniji element ističu adekvatan iznos tehničkih rezervi (TR). Visina TR daje kritički uvid u brojne aspekte poslovanja osiguravača, što može biti koristan indikator za kreiranje buduće

* Korespondencija: Z. Đurić, Ekonomski fakultet Univerziteta u Kragujevcu, Đ. Pucara 3, 34000 Kragujevac, Republika Srbija; e-mail: zdjuric@kg.ac.rs poslovne politike. Supervizorski organi, kroz prizmu zakonske regulative i opšteprihvaćenih međunarodnih računovodstvenih standarda poslovanja, u poseban fokus stavljaju visinu TR i njihovu mobilnost, da u svakom trenutku odgovore na zahteve korisnika.

Značaj adekvatnog obračuna TR u neživotnom osiguranju rezultirao je brojnim studijama na nivou Evropske unije: H. Müller-ov izveštaj (1997), G. Manghetti-jev izveštaj (2000), KPMG izveštaj (2002), izveštaj radne grupe o solventnosti neživotnih 
osiguravajućih društava (European Commission, 2002), koje su ustanovile da je visina TR glavni uzrok nesolventnosti neživotnih OD, jer postoje brojne nekonzistentnosti u njihovom kvantifikovanju. Osim toga, ni postojeći standardi ne daju jasan odgovor na brojna pitanja o kvalitetu metoda za procenu njihovog kvantiteta. „Primer standarda koji ostavlja značajan prostor za širok spektar računovodstvenih praksi jeste IFRS 4, koji se odnosi samo na opšta pitanja računovodstvenog tretmana ugovora o osiguranju, a ne nudi rešenja za sve probleme $u$ ovom području" (Obradovic 2014).

Problemi finansijske sigurnosti ispleli su mrežu interesovanja različitih matematičkih, finansijskih, statističkih, pa i medicinskih nauka uz veliku implementaciju informatičkih dostignuća. Inherentna neizvesnost o frekvenciji, broju, visini i vremenskom horizontu isplata odštetnih zahteva korisnika osiguranja još uvek su u žiži interesovanja brojnih istraživača. Bibliografiju brojnih publikacija o navedenoj problematici, kako u formi knjiga i monografija tako i naučnih radova, dao je K. D. Schmidt (2011).

Konsultovanjem brojne, kako inostrane, tako i domaće literature, uočen je nedostatak istraživačkih interesovanja za rezervaciju šteta neživotnih osiguravača u domaćim akademskim krugovima. Ova činjenica je, kao predmet istraživanja ovog rada, opredelila analizu metodologije obračuna rezervisanih šteta $\mathrm{u}$ aktuarskoj praksi neživotnih osiguravača Republike Srbije (RS).

Primarni cilj rada je komparativna analiza rezultata dobijenih primenom različitih metoda obračuna najneizvesnije komponente TR - rezervi za nastale neprijavljene štete. Kako je ovaj element tehničkih rezervi najdiskutabilniji i u fokusu istraživanja svetskih aktuarskih autoriteta, izvedeni cilj istraživanja je mogućnost primene njihovih percepcija na domaćem, nerazvijenom tržištu osiguranja.

Shodno postavljenom predmetu i ciljevima istraživanja, u radu je testirana osnovna hipoteza:

$\mathrm{H}_{0}$ : Projekcije kumulativnih iznosa budućih novčanih kompenzacija treba inflatorno korigovati.
Ova hipoteza indukovala je dodatnu hipotezu:

$\mathrm{H}_{1}$ : Metodologiju, zahtevanu od supervizorskih organa, treba preispitati, kroz trenutni redizajn zakonske regulative osiguranja.

Testiranje postavljenih hipoteza zahtevalo je dve vrste istraživanja. Osnovna hipoteza je jedan pravac istraživanja usmerila na komparativnu analizu dobijenih rezultata obračuna rezervi za nastale neprijavljene štete, primenom načešće korišćenih metoda u svetskoj aktuarskoj praksi. Koristeći konkretne rezultate poslovanja jednog osiguravajućeg društva, u jednoj liniji poslovanja sa dugim razvojem šteta (2006-2015), primenjene su različite metode njihove rezervacije kao i komparativna analiza projekcija njihovog iznosa sa isplatama u sledećoj godini poslovanja. Dodatna hipoteza je drugi pravac istraživanja usmerila na metodologiju obračuna tehničkih rezervi prisutnu u praksi osiguravajućih društava na domaćem tržištu. Upitnik sa 32 pitanja o metodologiji obračuna pojedinih komponenata tehničkih rezervi, distribuiran je 2014, kako neživotnim tako i kompozitnim osiguravajućim društvima koja posluju na teritoriji RS. Na osnovu odgovora pristiglih iz 11 osiguravajućih društava, uočeno je da je praksa $u$ rezervaciji šteta uslovljena metodologijom zahtevanom od supervizora njihovog poslovanja, uz nedostatak raspoloživog kadra pa samim tim i neophodnog vremena za aktuarsko angažovanje na sličnim istraživanjima.

Oba pravca istraživanja praćena su kako kvantitativnom metodologijom, prisutnom $u$ obračunu tehničkih rezervi, tako i kvalitativnom metodologijom, kroz konsultovanje relevantne literature $\mathrm{i}$ anketiranje domaćih praktičara $\mathrm{u}$ ovoj oblasti.

Rad je struktuiran $\mathrm{u}$ četiri celine. Nakon uvodnih razmatranja o posmatranoj problematici, u prvom delu rada, kroz šest podsekcija, dat je pregled najčešće korišćenih determinističkih metoda rezervacije šteta, uz pregled relevantnih naučnih rezultata. U sledećem delu, izdvojene metode su primenjene na realizacijama isplaćenih odštetnih zahteva jednog osiguravajućeg društva u cilju projektovanja budućih isplata. Osim primenjene kvantitativne metodologije, 
kroz 42 projekcije kako dinarskih, tako i evro iznosa rezervi za nastale neprijavljene štete, interpretirana je i kvalitativna metodologija istraživanja, izvršena anketiranjem aktuara neživotnih osiguravajućih društava. U zaključnim razmatranjima sumirani su rezultati oba pravca istraživanja, komparativnom analizom rezultata rezervacije šteta, i odgovora na distribuirani upitnik. Identifikujući ključne doprinose, ali i ograničenja prezentiranih istraživanja, precizirani su stavovi o postavljenim naučnim hipotezama i ukazano na pravce budućih istraživanja.

\section{DETERMINISTIČKE METODE REZERVACIJE ŠTETA}

Imajući u vidu potencijalni značaj TR, kao i uticaj neizvesnosti $u$ njihovim projekcijama, razvijene su brojne metode, koje se generalno mogu klasifikovati na determinističke i stohastičke. Determinističke tehnike daju aktuarsku procenu vrednosti mogućih kumulativnih iznosa budućih isplata, na osnovu dijagnostikovanih iskustava iz prethodnih perioda poslovanja. Pri tome, raspoložive determinističke metode ne pružaju i konkretnu meru odstupanja dobijene projekcije od mogućih realizacija šteta. Svesni tog nedostatka, aktuari primenjuju različite metode predviđanja za dobijanje procene potencijalnih šteta. Međutim, ma koliko da je širok raspon ovih projekcija, ostaje otvoreno pitanje koji iznos može reprezentovati optimalnu procenu, ili bar kolika je disperzija razumne procene.

Određivanje optimalne procene rezervi usko je povezano sa apsorbovanjem nedostataka tradicionalnih determinističkih tehnika. Kako je metoda lančanih lestvica (chain ladder method), često polazna metoda u rezervisanju, njenu stohastičku modifikaciju su istraživali brojni autori, među kojima su: E. Kremer (1982), G. C. Taylor i F. R. Ashe (1983), K. D. Schmidt i A. Schnaus (1996), A. E. Renshaw i R. J. Verrall (1998), Th. Mack i G. Venter (2000), G. C. Taylor (2000), P. D. England i R. J. Verrall (2002). Međutim, sofisticiranost stohastičkih modela zahteva znatne vremenske i druge resurse, tako da komercijalni imperativ u brzini dobijanja željenih projekcija ostavlja primenu stohastičkih modela u domenu akademskih istraživanja.

Determinističke metode polaze od pretpostavke da se isplate odštetnih zahteva u budućnosti mogu projektovati praćenjem i analizom prethodnih iskustava u određenim linijama poslovanja. Najrasprostranjeniji format prikazivanja i analiziranja podataka je tabelarni oblik, gde podaci mogu biti sistematizovani prema: broju nastalih šteta, broju likvidiranih šteta, iznosima prijavljenih šteta ili iznosima isplaćenih šteta. Kako je primarni fokus aktuara na potencijalnim isplatama $u$ sledećem obračunskom periodu, u analizama je najčešće analiziranje iznosa isplaćenih šteta $u$ prethodnim obračunskim periodima, koji mogu biti godišnji, polugodišnji ili kvartalni. Podaci u jednoj vrsti tabelarnog prikaza odnose se na istu godinu nastanka štete, dok kolone predstavljaju obračunske periode koji su protekli od trenutka nastupanja do trenutka isplate štete. Iznosi u kolonama odgovaraju istom periodu odlaganja dok su na dijagonali iznosi koji su isplaćeni $\mathrm{u}$ istoj kalendarskoj godini.

Slučajna promenljiva $X_{i, j}$ je iznos šteta nastalih $\mathrm{u}$ godini $i$, a isplaćenih nakon $j-1$ godine razvoja od dana nastanka štete. $U$ tabeli su opservabilne one vrednosti za koje je: $i+j \leq n+1$, zbog čega se ovaj tabelarni prikaz još naziva i trougao šteta (run-off trougao). Aktuarske studije tarifiranja i rezervacije šteta koriste trouglove šteta sa individualnim iznosima $X_{i, j}$ isplata šteta $u$ određenom periodu posmatranja $i$ kumulativnim iznosima $S_{i, j}$ šteta nastalih u godini $i$, a isplaćenih nakon $j-1$ godine razvoja od dana nastanka štete (Schmidt, 2006), tj.

$$
S_{i, j}=\sum_{k=1}^{j} X_{i, k}, \quad i=1,2, . ., n, j=1,2, \ldots, n-i+1
$$

Tradicionalne, determinističke metode rezervacije šteta se mogu grupisati $u$ dve velike familije: metode lančanih indeksa i metode stope šteta. 


\section{Metodološki okvir metoda lančanih indeksa}

Generalno, sve projekcije upotrebom lančanih indeksa zasnivaju se na sledećim koracima: određivanje lančanih indeksa, izbor prosečnog razvojnog faktora, a zatim, izračunavanje kumulativnih faktora razvoja, izbor rep-faktora (tail-faktora) i dobijanje projekcija budućih isplata odštetnih zahteva i rezervi za sledeće obračunske periode (Faculty and Institute of Actuaries, 1997).

Osnovna ideja metode lančanih indeksa je da postoji pravilnost $\mathrm{u}$ isplatama šteta, prema periodima odlaganja isplate šteta. Pri tome se upoređuju iznosi isplaćenih šteta u sukcesivnim periodima razvoja, odnosno, prati se procentualni priraštaj kumulativnih plaćanja. Količnik dva susedna iznosa u godini porekla predstavlja lančani indeks (age-to-age factor, development factor, link ratio) (Schmidt, 2006):

$$
f_{i, j}=\frac{S_{i, j+1}}{S_{i, j}}, \quad i=1,2, . ., n, j=1,2, \ldots, n-i .
$$

Uz navedenu pretpostavku, vrednost budućih isplata osiguranicima dobijamo preko očekivane vrednosti uslovnih verovatnoća (Dahl, 2003):

$$
E\left[S_{i, j+1} \mid S_{i, 1}, S_{i, 2}, \ldots ., S_{i, j}\right]=S_{i, j} \cdot r_{j}
$$

gde $r_{j}$ predstavlja izabrani razvojni faktor (FR). Ako obe strane prethodne jednakosti podelimo sa $S_{i, j}$ dobijamo:

$$
E\left[S_{i, j+1} / S_{i, j} \mid S_{i, 1}, S_{i, 2}, \ldots ., S_{i, j}\right]=r_{j} .
$$

Kako su iznosi $S_{i, j}$ i $S_{k, l}$ nezavisni za $i \neq k \mathrm{i} j \neq l \mathrm{i}$ razvojni faktor $r_{j}$ ne zavisi od godine porekla $i$. Predviđanje iznosa $S_{i, j}$ za $j \geq n-i+2$ je bazirano na sledećem rezultatu (Dahl, 2003):
Lema 1: Ako je $E[Z]$ konačno, tada je $E[Z]=E[E[Z \mid X]]$.

Polazeći od pretpostavke 3, primenom Leme 1 dobijamo:

$$
\begin{aligned}
& E\left[S_{i, j+t} \mid S_{i, 1}, S_{i, 2}, \ldots, S_{i, j}\right]=E\left[E\left[S_{i, j+1} \mid S_{i, 1}, S_{i, 2}, \ldots, S_{i, j, t-1}\right] S_{S_{i, 1},} S_{i, 2}, \ldots, S_{i, j}\right]= \\
& =E\left[S_{i, j+k-1} \cdot r_{j+k-1} \mid S_{i, 1}, S_{i, 2}, \ldots, S_{i, j}\right]=E\left[S_{i, j+k-1} \mid S_{i, 1}, S_{i, 2}, \ldots, S_{i, j}\right] \cdot r_{i t k-1}= \\
& =E\left[E\left[\left[_{i, j+t \mid} \mid S_{i, 1}, S_{i, 2}, \ldots, S_{i, j+k-2}\right] S_{i, 1}, S_{i, 2}, \ldots, S_{i, j}\right] \cdot r_{j+t k-1}=\right.
\end{aligned}
$$

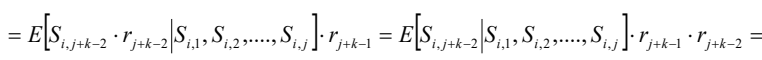

$$
\begin{aligned}
& =S_{i, j} \cdot r_{j+1} \cdot r_{j+2} \cdot \ldots \cdot \cdot r_{j+k-1}
\end{aligned}
$$

Znači:

$$
\begin{aligned}
& E\left[S_{i, j+k} \mid S_{i, 1}, S_{i, 2}, \ldots ., S_{i, j}\right] \\
& =S_{i, j} \cdot r_{j+1} \cdot r_{j+2} \cdot \ldots . \cdot r_{j+k-1}
\end{aligned}
$$

Ovaj rezultat sugeriše proceduru dobijanja svih vrednosti $S_{i, j^{\prime}}$ za svako $j \in(n-i+2, \ldots, n)$.

Neophodne novčane rezerve koje društvo formira utvrđuju se preko:

$$
R_{i}=E\left[S_{i, n}\right]-S_{n-i+1} \quad, i=1,2, \ldots, n
$$

Formula (5) ukazuje na činjenicu da je izbor prosečnog faktora razvoja $r$, za svaki razvojni period, bitan za dobijanje željenih projekcija.

Razvojni trougao šteta nije kompletan sve dok svi zahtevi, bar u najstarijoj godini porekla, nisu izmireni, tako da ni konačni troškovi za bilo koju godinu nisu poznati. Kao odgovor na to, aktuari dopunjavaju lančane indekse, dobijene iz raspoloživih podataka trougla, sa koeficijentom ostatka, odnosno, sa "rep” faktorom, koji procenjuje isplate izvan poslednje faze razvoja za koju se lančani indeks može izračunati. Istraživački interes određivanja koeficijenta ostatka $(\mathrm{KO})$ je rezultirao brojnim radovima i metodama, a 
radna grupa američkog udruženja aktuara Casualty Actuarial Society - CAS (2013) je dala njihov prikaz u studiji: The estimation of loss development tail factors: A summary report, CAS Tail Factor Working Party. U navedenoj studiji identifikovano je više metoda koje su grupisane $\mathrm{u}$ šest osnovnih kategorija: Bondi metode, Algebarske metode, Benchmark metode, Metode krivih linija, Metode zasnovane na preostalim neisplaćenim odštetnim zahtevima, i Metode zasnovane na specifičnostima preostalih otvorenih zahteva.

Grupa Bondi metoda je najrasprostranjenija u praksi zbog svoje jednostavnosti, mada rezultujući KO, dobijen njihovom primenom, može dati loše projekcije kod linija osiguranja sa dugim razvojem šteta. Osnovna metoda, koju je predložio M. Bondy, opravdava korišćenje poslednjeg lančanog indeksa kao prediktora budućeg razvoja šteta (Boor, 2006), odnosno, $f_{i, n+1}=f_{i, n}$. Kako se KO određuje za svaku godinu porekla, u oznakama se može izostaviti indeks $i$, dok se svaki lančani indeks posmatra u obliku $f_{j}=1+v(j)$, gde $v(j)$ predstavlja razvojni deo koeficijenta ostatka. Razvijene su razne modifikacije osnovne Bondi metode. Jedna od njih pretpostavlja da se razvojni deo lančanog indeksa smanjuje za $50 \%$, tj. da je $f_{j+1}=1+0,5 v(j)$, dok alternativne metode predlažu da se razvojni deo poslednjeg indeksa multiplikuje dvojkom ili kvadrira, tj. $f_{j+1}=1+2 v(j)$ ili $f_{j+1}=1+$ $v^{2}(j)$. P. J. Weller je generalizovao osnovnu metodu koristeći prosek tri poslednja razvoja, dok potpuna generalizacija tretira $\mathrm{KO}$ u obliku $f_{n}=(f n-1)^{B / B-1}$, gde je $B$ - Bondijeva konstanta, odnosno, broj između 0 i 1 (CAS Tail Factor Working Party, 2013).

Algebarske metode se fokusiraju na odnos između plaćenih i prijavljenih šteta. Njihova prednost je $\mathrm{u}$ tome što se zasnivaju isključivo na informacijama $u$ samom trouglu. Reprezentativni predstavnik ovih metoda je Sherman-Boor-ov algoritam (Sherman \& Diss, 2005; Boor, 2006), čija je primena aktuelizovana u aktuarskoj praksi tokom poslednjih godina. Mogući pristup proceni $\mathrm{KO}$ je pretpostavka o postojanju geometrijskog odnosa između lančanih indeksa, u zavisnosti od perioda odlaganja isplate šteta. Najčešće korišćena je metoda određivanja eksponencijalne stope opadanja, koja koristi lančane indekse $f\left(d_{i}\right)$, za kumulativne ili inkrementalne iznose plaćenih šteta.
Pri tome se svaki lančani indeks tretira kao funkcija razvojnog dela tj. $f\left(d_{\text {. }}\right)=1+v\left(d_{\text {. }}\right)$, uz pretpostavku da razvojni deo $v\left(d_{i}\right)$ opada po konstantnoj stopi $r$, odnosno da je $v\left(\mathrm{~d}_{i+1}\right)=v\left(d_{i}\right) \cdot r$ (Boor, 2006). Proces se sastoji od postavljanja eksponencijalne krive za razvojne delove $v\left(d_{i}\right)$. Konstanta opadanja $r$ može biti procenjena pomoću linearnog trenda vrednosti prirodnog logaritma razvojnih delova, a zatim se $\mathrm{KO}$, za razvojni period $d$, može proceniti kao:

$$
T(d)=1+v(d) \cdot \sum_{m=1}^{\infty} r^{m} .
$$

C. L. McClenahan (1975) inicirao je tehniku određivanja teorijske krive, uz pretpostavku da inkrementalne plaćene štete opadaju po konstantnoj mesečnoj stopi $r$, ali nakon nekoliko meseci $a, u$ kojima nije bilo isplata. Prateći eksponencijalni trend razvojnih delova lančanih indeksa i odgovarajućih novčanih vrednosti, određuje se njihova mesečna stopa opadanja $r$, na osnovu koje se KO dobija po formuli:

$\left.T=\{12 \times(1-p)\} /\left\{12 \times(1-p)-p^{m-a-10} \times\left(1-p^{12}\right)\right]\right\}$.

D. Skurnick je pojednostavio ovu metodu (Boor, 2006), posmatrajući godišnju stopu opadanja inkrementalnih isplata koja je proporcionalna najnovijoj isplati, dok se za svaku godinu nastupanja šteta određuje odgovarajuća stopa eksponencijalnog raspada i odgovarajući KO, po obrascu: $T=\frac{1-r}{1-r-r^{y}}$, gde y označava broj godina razvoja na koji će se $\mathrm{KO}$ primenjivati.

Određivanje KO je i dalje u fokusu brojnih istraživača, jer njegova vrednost bitno utiče na projekcije isplata u sledećim godinama. Usled odgovarajućih pretpostavki, ni jedna metoda ne može sa sigurnošću dati validan rezultat, ali testirajući njegovu vrednost, primenom različitih metoda, može se dobiti optimalni koeficijent daljeg razvoja isplate šteta.

\section{Metoda lančanih lestvica}

Metoda lančanih lestvica je najčešće korišćena $u$ aktuarskoj praksi, u domaćim, i u inostranim OD. P. D. England i R. J. Verrall (2002) navode da osnovni cilj 
svih ostalih determinističkih metoda je komparativna analiza sa rezultatima dobijenim metodom CL. Nasuprot tome, J. N. Stanard (1985), P. Narayan i T. V. Warthen (1997), G. Barnett i B. Zehnwirht (2000), G. C. Taylor (2000) fokusiraju svoja istraživanja na analizu ključnih pretpostavki ove metode i ispituju komparativnu adekvatnost ove metode rezervacije za različite vrste osiguranja.

Osnovna karakteristika CL metode je odgovarajuće ponderisanje. Polazeći od činjenice da je svaki količnik u koloni ponderisan iznosom štete iz koje je nastao, ova metoda koristi originalne pondere, tako da je razvojni faktor (Schmidt, 2006):

$$
r_{j}=\frac{\sum_{i=1}^{n-j+1} S_{i, j}}{\sum_{i=1}^{n-j+1} S_{i, j-1}}, j=1,2, \ldots, n-i
$$

\section{Metode zasnovane na stopi šteta}

Projekcije isplata koje će OD imati u budućim obračunskim periodima su zasnovane na pretpostavkama, tako da se svaki dobijeni rezultat mora prihvatiti sa odeđenim stepenom poverenja. Nedostatak metoda zasnovanih na lančanim indeksima se reflektuje kod najnovijih godina $\mathrm{u}$ kojima su nastupile štete, jer je njihov dalji razvoj do konačnih isplata veoma dug. Upravo zbog toga, faktori razvoja, dobijeni iz dosadašnjeg iskustva, su relativno visoki i podložni brojnim fluktuacijama, koje su u posmatranom trenutku neizvesne.

Alternativni pristup, relativno jednostavan za upotrebu, je korišćenje stope šteta, koja ukazuje procentualno učešće ukupnih isplaćenih šteta u premijama koje je osiguravač naplatio. Poenta adekvatne primene koncepta stope šteta je da premija treba da odgovara periodu izloženosti riziku. Samim tim, ako se koriste trouglovi šteta sa štetama prezentiranim po godinama nastanka štete, tada iznose konačnih plaćanja treba porediti sa zarađenom premijom (Schmidt, 2008). U slučaju prezentovanja podataka po godinama početka osiguravajućeg pokrića indikativna mera je fakturisana premija. Najjednostavniji pristup je da se, na osnovu dosadašnje stope šteta i zarađene premije, odredi agregatni monetarni iznos budućih plaćanja, koji, kada umanjimo za dosada izvršene isplate, daje iznos neophodnih rezervi (Saluz, Gisler \& Wüthrich, 2011). Primena ovog postupka ima veću stabilnost rezultata, posebno kod malih serija, ili u slučaju pokretanja nove linije osiguranja. Osnovni nedostatak je što je oslonjen na a priori informacije, ne uvažavajući, pri tome, realizacije koje su već nastupile.

\section{Metoda prosečnog troška}

Pretpostavka metode prosečnog troška po šteti je da prosečan iznos šteta i njihov broj, za svaku razvojnu godinu, su u konstantnom odnosu sa ukupnim brojem i iznosom šteta za posmatranu godinu. Primena ove metode se zasniva na korišćenju podataka o broju podnetih zahteva i iznosu nastalih šteta. Može se primeniti na isplaćene ili prijavljene štete, pri čemu i broj šteta mora odgovarati obliku korišćenih iznosa. Pravilo je da iznose isplaćenih šteta treba upoređivati sa brojem rešenih šteta, dok je broj prijavljenih šteta pandan iznosu nastalih šteta. Bilo koje grupe konzistentnih podataka, deljenjem daju iznos prosečnog troška po nastalom odštetnom zahtevu. Ovi troškovi se, zatim, projektuju do konačnih iznosa individualnih troškova, u svakoj razvojnoj godini, primenom bruto faktora. $\mathrm{Na}$ isti način se generiše i broj očekivanih odštetnih zahteva koji, kada se kao multiplikator primeni na očekivani prosečni iznos štete, projektuje iznos ukupnih obaveza OD. Neophodnu rezervu dobijamo ako dobijeni iznos smanjimo za iznos isplaćenih odšteta.

Ovakva projekcija može biti korisna, jer analiza iskustva o iznosu i broju odštetnih zahteva omogućava ispitivanje trendova u prijavi šteta i njihovoj likvidaciji, kao i u prosečnom iznosu šteta. Sama metoda može dati kvalitetne odgovore, posebno u slučajevima organizacionih ili spoljašnjih fluktacija, ali isto tako može pomoći u detekciji adekvatnosti drugih aktuarskih tehnika projekcije. Ona se može primeniti na podatke agregirane po godinama nastanka šteta, godinama podnošenja 
zahteva, godinama početka osiguranja, ili po samoj kalendarskoj godini. Iako se može primeniti na sve vrste osiguranja, češća je upotreba kod linija sa dugim razvojem šteta.

\section{Bornhutter-Ferguson-ova metoda (BF)}

Bornhutter-Ferguson-ova metoda kombinuje koncept prosečnog troška i lančane indekse. Inicijalna, realna pretpostavka je da se ukupan gubitak, u svakoj godini poslovanja, može podeliti na prošli i budući deo, koji se analiziraju odvojeno. Prvi deo procene, koji se odnosi na ostvarene realizacije je poznat, ili adekvatno procenjen, uzimajući u obzir rezerve za prijavljene, ali neisplaćene štete. Neizvesnost, sadržana u budućim realizacijama, ne vezuje se za isti obrazac istorijskih realizacija, već se tretira pomoću opštije procene, bazirane na količniku šteta za datu klasu osiguranja. Sumiranjem ove dve procene dobijamo osetljiviju procenu mogućih konačnih isplata, a samim tim i neophodnih rezervi.

Ako se prate iznosi kumulativnih isplata, $S_{i, j^{\prime}}$ koji su promenljive nezavisne od godine porekla $i$, pretpostavka BF metode je da postoje parametri $\alpha_{1^{\prime}} \alpha_{2^{\prime} . .,} \alpha_{n}$ i stope $\beta_{1^{\prime}} \beta_{2^{\prime} . . .} \beta_{n^{\prime}}$ gde je $\beta_{n}=$ 1 (jer je razvoj za prvu godinu porekla završen), koji se koriste za projekciju prošlog i budućeg dela ukupnih isplata (Mack, 2006), tako da je $\forall i: 1 \leq i \leq n, \quad \forall j: 1 \leq j \leq n-1$ :

$$
\begin{aligned}
& E\left[S_{i, 1}\right]=\alpha_{i} \cdot \beta_{1}, \mathrm{i} \\
& E\left[S_{i, j+k} \mid S_{i, 1}, S_{i, 2}, \ldots, S_{i, j}\right]=S_{i, j}+\left(\beta_{j+k}-\beta_{j}\right) \cdot \alpha_{i}
\end{aligned}
$$

Kako su $S_{i, j}$ kumulativni iznosi, samim tim su i $\alpha_{j}$ kumulativni KO. Prema (8) sada je:

$$
E\left[S_{i, j}\right]=\alpha_{i} \cdot \beta_{j} \quad \text { i } E\left[S_{i, n}\right]=\alpha_{i}
$$

Polazeći od ove relacije, za $\forall i: 1 \leq i \leq n, \quad \forall j: 1 \leq j \leq n-i+1$, dobijamo da je (Mack, 2008):

$$
E\left[S_{i, n} \mid S_{i, 1}, S_{i, 2}, \ldots, S_{i, j}\right]=S_{i, j}+E\left[S_{i, n}-S_{i, n-i+1}\right],
$$

što prema bazičnim pretpostavkama implicira:

$$
\begin{aligned}
& E\left[S_{i, n} \mid S_{i, 1}, S_{i, 2}, \ldots, S_{i, j}\right]= \\
& =S_{i, j}+\left(\beta_{n}-\beta_{n-i}\right) \cdot \alpha_{i}= \\
& =S_{i, j}+\left(1-\beta_{n-i+1}\right) \cdot \alpha_{i}
\end{aligned}
$$

BF projekcija je tada (Schmidt, 2008):

$$
E\left[S_{i, n}\right]=S_{i, n-i+1}+\left(1-\beta_{n-i+1}\right) \cdot \alpha_{i}
$$

gde je $\beta_{n-i+1}$-a posteriori procena, a $\alpha_{i}$-a priori procena konačnih šteta.

Kako je kod CL metode:

$$
E\left[S_{i, n} \mid S_{i, 1}, S_{i, 2}, \ldots, S_{i, j}\right]=E\left[S_{i, j}\right] \cdot \prod_{k=j+1}^{n-1} r_{k}=E\left[S_{i, 1}\right] \cdot \prod_{k=1}^{n-1} r_{k},
$$

dobija se da je: $E\left[S_{i, j}\right]=E\left[S_{i, n}\right] \cdot \prod_{k=0}^{n-1} r_{k}^{-1}$.

Ako ovaj rezultat uporedimo sa (9) očigledno je:

$$
\beta_{j}=\prod_{k=j+1}^{n-1} r_{k}^{-1}
$$

tako da (11) sada postaje:

$$
E\left[S_{i, n}\right]=S_{i, n-i+1}+\left(1-\frac{1}{\prod_{k=n-i+1}^{n-1} r_{k}}\right) \cdot \alpha_{i}
$$

Ova relacija ukazuje na bitnu razliku BF i CL metode, koja se sastoji u izboru parametara procene. Kod CL metode je (Schmidt, 2008): 


$$
\begin{aligned}
& E\left[S_{i, n}\right]=S_{n-i+1} \cdot \prod_{k=n-i+1}^{n-1} r_{k}= \\
& =S_{n-i+1}+S_{n-i+1} \cdot\left(\prod_{k=n-i+1}^{n-1} r_{k}-1\right)= \\
& =S_{n-i+1}+\frac{E\left[S_{i, n}\right]}{\prod_{k=n-i+1}^{n-1} r_{k}} \cdot\left(\prod_{k=n-i+1}^{n-1} r_{k}-1\right)
\end{aligned}
$$

tako da je:

$$
E\left[S_{i, n}\right]=S_{n-i+1}+\left(1-\frac{1}{\prod_{k=n-i+1}^{n-1} r_{k}}\right) \cdot E\left[S_{i, n}\right]
$$

Razlika između (13) i (14) je u poslednjem članu procene: kod CL metode on je dobijen iz opservabilnih podataka, dok BF metoda dozvoljava da $\alpha_{i}$ bude bilo koji estimator konačnog razvoja šteta. Stoga je parametar $\alpha_{i}$ a priori egzogeni faktor, dobijen nekom drugom stručnom ekspertizom. Aplikacija BF metode je, uglavnom, bazirana na primeni stope šteta i zarađene premije, kao $\alpha$ prediktora konačnih šteta. Kako količnik šteta ukazuje na istorijsko iskustvo iz poslovanja OD o procentualnom učešću šteta $u$ premijama, ovaj proizvod nam ukazuje na potencijalni iznos očekivanih šteta u narednoj godini poslovanja. Kod CL procene, inverzni proizvod razvojnih faktora ukazuje na procentualni iznos isplaćenih šteta $\mathrm{u}$ ukupno očekivanoj isplati za datu razvojnu godinu, tako da: $1-1 / \prod_{k=n-i+1}^{n-1} r_{k}$ predstavlja procentualni iznos neisplaćenih očekivanih šteta. Ako se projekcija mogućih šteta, po razvojnim godinama, dobije pomoću stope šteta i premije, proizvod ovog iznosa i faktora: $1-1 / \prod_{k=n-i+1}^{n-1} r_{k}$ daje iznos neophodne rezerve (Schmidt, 2008).

Za razliku od metode očekivanih šteta, gde projekcija ignoriše stvarne realizacije i metode lančanih indeksa, gde se pun kredibilitet daje isplaćenim štetama, BF metoda se oslanja na podatke iz prošlosti, ali ne kao jedinog repera, za procenu budućih plaćanja. Razvojem šteta, kredibilitet projekcije se bazira na razvoju šteta $\mathrm{u}$ novijim iskustvenim periodima, tako da ponder iz polaznih realizacija opada (Martínez-Miranda, Nielsen \& Verrall, 2013). Nastale neprijavljene štete će se $u$ budućnosti razvijati na osnovu očekivanih isplata, nastale realizacije nisu prediktori budućeg razvoja, pa ni fluktacije isplata u ranim fazama ne narušavaju projekciju potrebnih rezervi. To je zapravo i glavni argument upotrebe metode BF kod onih vrsta osiguranja gde štete $\mathrm{i}$ isplate mogu trajati više godina ali i u slučaju drugih linija osiguranja, gde su izražene fluktacije u realizacijama nastalih isplata.

\section{Stanard-Bühlmann-ova metoda}

Ovu metodu, poznatu još i kao Cape-Code (CC) metodu, su nezavisno razvili J. N. Stanard (1985) i H. Bühlmann (1983), kao korekciju BF metode. Pri tome, zadržana je polazna pretpostavka, o podeli konačnih šteta na prijavljene i očekivane neprijavljene štete, uz korekciju određivanja stope šteta. Za razliku od BF metode, gde je stopa šteta procenjena od strane lica koje obračunava rezerve, kod CC metode je očekivana stopa šteta određena na osnovu istorijskog iskustva o ukupnom iznosu prijavljenih šteta. Za svaku razvojnu godinu, stopa šteta je izračunata na osnovu ukupno prijavljenih šteta i zarađene premije, dok očekivana stopa za sledeći razvojni period, predstavlja ponderisani prosek svih dobijenih stopa. Kako su očekivane štete bazirane na prijavljenim štetama, neophodan je veliki obim podataka, što često limitira primenu ove metode. „Nestašica kvalitetnih podataka je kritičan faktor, jer sa neadekvatnim podacima, čak i savršen model neće dati rezultate" (Kočović, Mitrašević, Kočović i Jovović, 2011).

\section{Metodologija obračunavanja rezervisanih šteta Narodne banke Srbije(NBS)}

Zakon o osiguranju u RS, odnosno, Odluka o bližim kriterijumima i načinu obračunavanja rezervisanih 
šteta, dozvoljava da se za obračun rezervi za nastale neprijavljene štete primeni neka od aktuarskih metoda ili da se rezervacija vrši na osnovu podataka o rešenim i rezervisanim nastalim prijavljenim a nerešenim štetama, bez uključivanja rentnih šteta. Takođe, obračun ne uključuje ni troškove povezane sa rešavanjem i isplatom šteta. Prema ovom principu, iznos rezervi za nastale neprijavljene štete, $u$ samopridržaju društva, u određenoj vrsti osiguranja, predstavlja zbir rešenih i prijavljenih nerešenih šteta u samopridržaju u određnoj vrsti osiguranja, korigovan koeficijentom za obračun nastalih neprijavljenih šteta, $t j$.

$$
R_{t}^{I B N R}=a_{t} \cdot\left(S_{t}+R_{t}\right)
$$

gde je $S_{t}$ iznos rešenih (bez rentnih) šteta $u$ samopridržaju u vrsti osiguranja, $R_{t}$ iznos rezervisanih (bez rentnih) nastalih prijavljenih a nerešenih šteta $u$ samopridržaju u vrsti osiguranja, $a_{t}$ koeficijent za obračun nastalih neprijavljenih šteta i $R t^{I B N R}$ rezultujući iznos nastalih neprijavljenih šteta u posmatranoj vrsti osiguranja (Službeni glasnik RS, 2007).

Koeficijent korekcije $a_{t}$ se obračunava 31. decembra tekuće godine, ukoliko poslovanje u određenoj vrsti osiguranja traje duže od tri godine (ili najmanje dve godine), i ne može biti manji od 0,1. On predstavlja aritmetičku sredinu koeficijenata $k_{i^{\prime}}$ obračunatih za tekuću i prethodne dve godine osiguranja. Koeficijent $k_{i}$ za svaku od poslednje tri, odnosno, dve godine, predstavlja količnik: 1) zbira iznosa šteta rešenih u toku godine i rezervisanih nastalih prijavljenih, a nerešenih šteta na dan 31. decembra, koje su nastale u prethodnom periodu, a prvi put prijavljene u godini za koju se utvrđuje ovaj koeficijent i 2) zbira iznosa šteta rešenih $u$ toku godine i rezervisanih nastalih prijavljenih, a nerešenih šteta na dan 31. decembra u godini za koju se utvrđuje taj koeficijent. Ukoliko poslovanje u određenoj vrsti traje manje od 2 godine, vrednost ovog koeficijenta je 0,1.

Ukoliko je rezerva za nastale neprijavljene štete obračunata nekom drugom metodom, njen iznos ne može biti manji od iznosa dobijenog na ovaj način, pri čemu i ovako obračunata rezerva ne sme biti manja od rezerve obračunate na kraju prethodne godine.

\section{METODOLOGIJA I REZULTATI ISTRAŽIVANJA}

Jedna od vodećih američkih kompanija za finansijske usluge - Standard \& Poor's (S\&P), nivo TR svodi na komparativnu analizu rezultata dobijenih na osnovu sledeće tri metodologije: razvoj plaćenih šteta, razvoj nastalih šteta i BF metode. Prema njihovoj analizi, triangulacione tehnike zasnovane na plaćenim i nastalim štetama, najadekvatnije rezultate daju uz petogodišnji ponderisani prosek FR šteta, koji najbolje održavaju ravnotežu između stabilnosti i pouzdanosti u razvijanju faktora (Standard \& Poor's Ratings Services, 2008).

Rezultati istraživanja, koje je sprovelo Društvo za konsalting i reviziju - KPMG na nivou Evropske unije (2002), pokazuju da komparativna analiza rezultata rezervacija, dobijenih primenom različitih aktuarskih tehnika, je opšte prihvaćeni način u minimiziranju odstupanja predloženih projekcija i realizacija isplata. Skoro u svim evropskim državama, najfrekventnija je upotreba metoda triangulacije, najčešće CL metode na kumulativne isplaćene štete $u$ prethodnim godinama poslovanja. Paralelno sa ovom metodom koristi se najmanje jedna od sledećih metoda: metoda stope šteta, metoda očekivanog prosečnog troška ili Bornhutter-Ferguson-ova metoda.

Sve navedene studije su inicirale istraživanje primenjene prakse kod neživotnih OD koja posluju u RS. Prema rezultatima ankete, koja je izvršena kod 11 neživotnih OD (od kojih su 2 u privatnom, a 9 u ino vlasništvu), aktuari su pri projekciji neizvesnih iznosa budućih isplata šteta, orijentisani na Odluku o bližim kriterijumima i načinu obračunavanja rezervisanih šteta NBS i na CL metodi. Zato je fokus istraživanja i usmeren na primenu različitih determinističkih metoda, sa namerom da se utvrdi da li je njihov izbor najadekvatniji, odnosno, da li neka druga metoda daje rezultate bliže realizacijama iz 2016.

Korišćeni su podaci o realizaciji isplata odštetnih zahteva jednog osiguravajućeg društva, u liniji osiguranja sa dugim razvojem šteta. Projekcije potencijalnih iznosa budućih isplata, izvršene su na metodama triangulacije, korišćenjem razvojnih 
trouglova plaćenih i prijavljenih, a neisplaćenih šteta, za period 2006-2015, kako bi rezultati mogli da se porede sa realizacijama ovih iznosa u 2016. Pri tome, projekcije su izvršene i za dinarske i za evro iznose, kako kod metoda triangulacije, tako i pri primeni BF i CC metode. Konverzija dinarskih u evro iznose izvršena je pomoću zvaničnog srednjeg kursa evra na dan 31. decembra.

Za svaku razvojnu godinu, izabrani su lančani indeksi, dobijeni kao: 1) konzervativni prosek, odnosno, izbor najvećeg lančanog indeksa $u$ posmatranom razvojnom periodu; 2) aritmetička sredina svih lančanih indeksa, po kolonama, za svaku godinu razvoja šteta; 3) aritmetička sredina poslednja tri lančana indeksa, u svakoj koloni; 4) aritmetička sredina poslednjih pet lančanih indeksa, u svakoj koloni; 5) medijalna sredina indeksa, tj. aritmetička sredina indeksa koji ostaju posle izbacivanja najveće i najmanje vrednosti indeksa u svakoj koloni; 6) geometrijska sredina, dobijena primenom funkcije GEOMEAN, programa Microsoft Office Exel 2007, odnosno, kao $\sqrt[n-1]{f_{1} \cdot f_{2} \cdot \ldots f_{n}}$, gde su $f_{1^{\prime}} f_{2^{2}}, \ldots, f_{n}$ lančani indeksi i 7) ponderisane sredine, primenom CL pondera.

Od brojnih tehnika određivanja tail faktora, korišćene su sledeće metode: Bondi metoda, koja izbor vrši na osnovu poslednjeg izračunatog lančanog indeksa za godinu koja ima najduži razvoj šteta i još dve modifikacije ove metode, gde se razvojni deo poslednjeg lančanog indeksa kvadrira ili udvostručuje; Sherman-Boor-ova metoda; Metoda eksponencijalne aproksimacije; McClenahan-ove metoda i Scurnick-ove metoda.

Za svaki razvojni faktor, određen na jedan od sedam pomenutih načina, koeficijent ostatka je određen primenom svih sedam metoda, a zatim izvršena projekcija budućih isplata svih nastalih neprijavljenih šteta za razvojni period 2006-2015. Na taj način, dobijeno je 49 projekcija samo kod metoda zasnovanih na lančanim indeksima. Rezultati dobijenih projekcija su upoređivani sa realizacijama isplata u 2016, za sve štete koje su nastale $u$ periodu 2006-2015. Kod metoda zasnovanih na lančanim indeksima, najbliži iznos stvarnim isplatama dala je metoda gde su razvojni faktori dobijeni preko medijalnog proseka uz koeficijent ostatka određen osnovnom Bondi metodom. Osim metoda lančanih indeksa, dobijen je i iznos ovih potencijalnih isplata metodom očekivanog troška, BF i CC metodom. Rezultati dobijenih projekcija nastalih neprijavljenih šteta u evro iznosima su dati u Tabeli 1, dok su rezultati projekcija izvršenih na isti način, ali u dinarima, prikazani u Tabeli 2.

Tabela 1 Komparativna analiza metoda projekcije $(\mathrm{u}$ evrima)

\begin{tabular}{l|l}
\hline Metoda & Projekcija \\
\hline Metoda lančanih indeksa & 12312428 \\
Metoda očekivanog troška & 13141133 \\
CL metoda sa Bondi KO & 12356404 \\
Bornhutter-Ferguson-ova metoda & 12359573 \\
Cape-Code metoda & 12232147 \\
\hline
\end{tabular}

Realizacija u 2016: 11728866

Izvor: Autori

Tabela 2 Komparativna analiza metoda projekcije (u dinarima)

\begin{tabular}{l|l}
\hline Metoda & Projekcija \\
\hline Metoda lančanih indeksa & 1578908008 \\
Metoda očekivanog troška & 1527416691 \\
CL metoda sa Bondi KO & 1623425309 \\
Bornhutter - Ferguson-ova metoda & 1659685804 \\
Cape - Code metoda & 3058845966 \\
Metodologija NBS & 1892155950 \\
\hline
\end{tabular}

Realizacija u 2016: 1344383096

Izvor: Autori

Pored kvantitativne komparativne analize, drugi pravac istraživanja je usmeren na aktuarsku praksu kod neživotnih OD koja posluju na teritoriji RS. Upitnik sa 32 pitanja, fokusirana na obračun pojedinih komponenata tehničkih rezervi distribuiran je 
kako osiguravajućim društvima koja se bave samo neživotnim osiguranjem, tako i kompozitnim osiguravajućim društvima, u cilju detektovanja divergencije $\mathrm{u}$ primenjenoj metodologiji.

Upitnik je sadržao sledeća pitanja: 1. Koje vrste neživotnih osiguranja $u$ portfelju ima Vaše osiguravajuće društvo? 2. Da li obračun tehničkih rezervi vrši ovlašćeni aktuar? 3. Koliko godina iskustva ima lice koje se bavi obračunom rezervi? 4. Koji procenat radnog vremena $\mathrm{u}$ toku godine odlazi na poslove obračuna rezervi? 5. Koje tehničke rezerve u neživotnom osiguranju formirate? 6 . Obračun prenosnih premija vrši se: a) metodom pro rata temporis, b) metodom dvadesetčetvrtina, c) kvartalnom metodom, d) metodom jednake stope? 7. Za označenu metodu u prethodnom pitanju objasnite kako vršite rezervaciju. 8. Obračun rezervi za nastale prijavljene a nerešene štete vrši se: a) metodom procene svake pojedinačne štete, b) metodom prosečne vrednosti, c) tabličnom metodom, d) metodom količnika šteta? 9. Za označenu metodu u prethodnom pitanju objasnite kako vršite rezervaciju. 10. Obračun rezervi za nastale neprijavljene štete vrši se: a) na osnovu podataka o rešenim i rezervisanim nastalim prijavljenim a nerešenim štetama (prema Odluci o bližim kriterijumima i načinu obračunavanja rezervisanih šteta), b) metodom očekivane kvote šteta, c) chain-ladder metodom, d) nekom drugom metodom (navedite kojom). 11. Za označenu metodu u prethodnom pitanju objasnite kako vršite rezervaciju. 12. Ukoliko koristite chain-ladder metodu navedite kako određujete razvojne faktore za projekciju budućih plaćanja. 13. Koliko razvojnih godina koristite u trouglovima za projekcije budućih šteta? 14. Da li određujete tail faktor i kako? 15. U razvojnim trouglovima koristite: a) iznose likvidiranih šteta, b) iznose likvidiranih šteta sa troškovima, c) iznose likvidiranih šteta + rezervisane nastale prijavljene a nerešene štete do kraja obračunskog perioda? 16. U trouglovima šteta koristite: a) datum nastanka štete, b) datum prijave štete, c) datum isplate štete? 17. Da li, po Vašem mišljenju, očekivanu inflaciju treba ukalkulisati u projekcije budućih šteta? 18. Da li u trouglove šteta unosite obaveze koje padaju na teret reosiguravača? 19. Koliko je prosečno odstupanje projektovanih rezervi i stvarno nastalih šteta? 20. Da li vršite procenu adekvatnosti projektovanih rezervi? 21. Kako vršite procenu adekvatnosti projektovanih rezervi? 22. Da li se obračun rezervacije troškova rešavanja, procene i likvidacije šteta vrši: a) primenom koeficijenta troškova šteta, u skladu sa Odlukom o bližim kriterijumima i načinu obračunavanja rezervisanih šteta, b) nekom drugom metodom? 23. Za označenu metodu u prethodnom pitanju objasnite kako vršite rezervaciju. 24 . Da li koristite statističke metode za projektovanje rezervi? 25. Navedite koje ste statističke metode koristili i koliko je korisna njihova primena. 26. Da li bi želeli i koliko da koristite statističke metode? 27. Obračun premijskih stopa za pojedine vrste poslovanja vrši se: a) metodom klasa, b) metodom procene premijskih stopa, c) iskustvenim odredjivanjem premijskih stopa, d) nekom drugom metodom (navedite kojom). 28. Za označenu metodu u prethodnom pitanju objasnite kako vršite obračun. 29. Da li se premijske stope koriguju, koliko često i kako? 30. Koji procenat tehničke premije čine varijabilni troškovi? 31. Koji procenat bruto premije čini režijski dodatak? 32. Da li imate neku sugestiju u vezi obračuna tehničkih rezervi?

Odgovor na distribuirani upitnik, stigao je iz 11 društava, od kojih su dva osiguravača sa domaćim kapitalom, koji se bave isključivo neživotnim osiguranjem, a ostalih 9 društava je u većinskom stranom vlasništvu, od kojih se, isključivo neživotnim osiguranjem bavi 7 osiguravača, dok dva osiguravača u svom portfelju imaju i životno osiguranje.

$\mathrm{Na}$ poslovima obračuna rezervi kod 81,82\% anketiranih osiguravača rade ovlašćeni aktuari, od kojih 45,45\% ima manje od 5 godina radnog iskustva na pomenutim poslovima. Aktuari domaćih osiguravača imaju preko 6 godina iskustva, ali oko $10 \%$ radnog vremena posvećuje obračunu rezervi, što je neadekvatno doprinosu koje njihovo iskustvo i praksa, mogu dati u razvoju i korekciji postojeće regulative ove problematike. Kod ostalih osiguravača, aktuari posvećuju od 5\% do čak 50\% radnog vremena valuaciji rezervi, sa radnim iskustvom na pomenutim poslovima od 3 do 6 godina. Metodologija, koju primenjuju zaposleni pri obračunu pojedinih komponenti rezervi, bazirana je na odlukama koje je donela Narodna banka Srbije. Rezerve za nastale, 
a do kraja obračunskog perioda neprijavljene štete aktuari određuju na više načina: $88,89 \%$ prema Odluci NBS, 33,33\% metodom očekivane stope šteta, a $77,78 \%$ primenjuje chain ladder (CL) metodu. U domaćim osiguravajućim društvima aktuari obračun ovih rezervi vrše prema Odluci NBS i CL metodi. Na pitanje o izboru razvojnih faktora kod CL metode, odgovori aktuara su različiti: tri aktuara koriste ponderisane proseke, dve medijalne, dok jedan aktuar (kod domaćeg osiguravača) navodi oba načina, uz primenu i aritmetičkih faktora za poslednje tri godine nastanka šteta.

Pitanje: Da li u trouglove šteta unosite obaveze koje padaju na teret reosiguravača? je podelilo osiguravače, kako strane tako i domaće: 5 aktuara ne registruje iznose predate $\mathrm{u}$ reosiguranje, dok 4 osiguravajuća društva, sasvim neopravdano, i ove iznose kalkulišu $\mathrm{u}$ iznose likvidiranih šteta. Prenošenje preuzetih rizika, preko samopridržaja društva, na reosiguravača relaksira obaveze budućih isplata, kao i odgovornost $\mathrm{u}$ isplati takvih šteta. Ovakva divergencija u praksi pravi velike razlike u kvantifikovanju rezervisanih iznosa osiguravača. Neopravdano korišćenje reosiguranih iznosa $u$ trouglovima šteta trebalo bi i zakonski ograničiti, jer je motivisano i neopravdanim dobijanjem poreskih olakšica. Čekajući primenu direktive Solventnost 2 na tržišnim prostorima RS, koja zabranjuje upotrebu ovih iznosa u projekcijama budućih novčanih tokova, upućuje na neophodnost intervencije revizora i Narodne banke Srbije, kao regulatora poslovanja osiguravača.

U trouglove šteta svi aktuari smeštaju iznose prema godini nastanka i godini isplate štete, a 28,57\% anketiranih unosi i iznose koji padaju na teret reosiguravača. Divergencija u praksi je prisutna, kako kod ino, tako i kod domaćih osiguravača. Ohrabruje činjenica da znanje zaposlenih aktuara teži ka naučnoj utemeljenosti poslova na kojima su angažovani, što bi trebao da bude dovoljan razlog da nadležni interni i eksterni organi mobilišu njihovu energiju i interes, kroz kontinuirano obrazovanje $\mathrm{u}$ cilju veće pripremljenosti našeg tržišta osiguranja za harmonizaciju sa složenom regulativom u Evropskoj uniji.
Kvantifikovanje rezervacije troškova rešavanja, procene i likvidacije šteta, $u$ nestabilnom poslovnom okruženju, suočenom sa rastućom nelojalnom konkurencijom u borbi za pridobijanjenovih korisnika, nije jednostavno. Neophodnost kvalitetnijeg načina i veće opreznosti u projekciji ovih iznosa potvrđuje uvid u bilans stanja i uspeha osiguravajućih društava, koja se bave neživotnim osiguranjem, na teritoriji RS, sa mišljenjem angažovanih revizora. Naime, na kraju 2013, analizirajući pojedine bilansne stavke, revizori su čak kod pet osiguravača (AS osiguranje, DDOR Novi Sad, Milenijum osiguranje, Sava osiguranje i Triglav osiguranje) naišli na neadekvatnost ovih rezervacija. Kod navedenih osiguravača, troškovi sprovođenja osiguranja u pojedinim vrstama osiguranja, znatno prevazilaze obračunati režijski dodatak (bilans stanja i uspeha sa mišljenjem revizora za sva osiguravajuća društva je dostupan na sajtu NBS). Ipak, prema pristiglim odgovorima, 10 aktuara rezervaciju ovih troškova vrši prema Odluci NBS o bližim kriterijumima i načinu obračunavanja rezervisanih šteta.

\section{ZAKLJUČAK}

Inherentna neizvesnost kako nastupanja, tako i visine šteta u neživotnom osiguranju, najjaču refleksiju ima na projekciju iznosa tehničkih rezervi. Brojni naučni radovi i studije usmereni su na dobijanje najbolje procene njihovog iznosa. Međutim, skoro da nije bilo empirijskih istraživanja ove problematike u domaćim akademskim aktuarskim radovima. Ova činjenica daje poseban značaj ovom radu, koji sadrži dva pravca empirijske analize.

Iz dobijenih rezultata istraživanja proizilaze sledeći zaključci:

- proračuni na trouglovima šteta sa evro iznosima, ukazali su da kod metoda zasnovanih na lančanim indeksima, najmanje odstupanje projekcije od isplaćenih šteta u 2016, daje primena razvijnih faktora dobijenih preko medijalnog proseka, sa koeficijentom ostatka po Bondi metodi; 
- komparativna analiza dobijenih projekcija evro iznosa rezervi za nastale neprijavljene štete ukazuje na činjenicu da se najadekvatnije predviđanje isplata u sledećoj godini dobija primenom CC metode, gde je odstupanje od stvarne realizacije $4,29 \%$, dok metoda očekivanog troška daje prekorezervisanje od 12,04\%. Bondi metoda sa medijalnim prosekom, kao najbolja metoda projekcije kod metoda triangulacije, odstupala je oko $5 \%$ od realizovanih isplata posmatranih šteta;

- kod projekcija rezervi u dinarskim iznosima, metoda očekivanog troška daje najmanje odstupanje $(+13,615 \%)$ od isplaćenih šteta u 2016, dok projekcija, primenom Odluke NBS, daje viši iznos rezervi za nastale neprijavljene štete od $40,745 \%$.

Kod neživotnih osiguravača, realizacija isplata šteta je najveća u prvoj godini osiguranja a kod mnogih linija osiguranja, osiguravajuće pokriće traje vrlo kratko. Ovi argumenti su bili dovoljni da regulatori poslovanja osiguravača na širokom polju Evropske unije do sada ne insistiraju na inflatornoj korekciji izvršenih projekcija. Nestabilnost tržišnih uslova, kao i visoka inflacija, koja prati poslovanje osiguravača mnogih zemalja u razvoju, svakako navode na potrebu projektovanja uz korekciju budućih isplata očekivanom inflacijom. Projekcija iznosa posmatrane komponente tehničkih rezervi $u$ odabranom osiguravajućem društvu, na jednoj liniji osiguranja, kao i komparativna analiza dobijenih rezultata ukazuju na činjenicu da deflacionisani podaci daju manja odstupanja očekivanih od realizovanih isplata. Najbolja metoda projekcije dinarskih iznosa je dala prekorezervisanje od $13 \%$, dok projekcija u evro iznosima odstupa oko $5 \%$ od realizacije, što potvrđuje postavljenu osnovnu hipotezu.

Analizirajući odgovore na pitanja iz Upitnika, primećen je nedovoljan broj aktuara angažovanih za obračun tehničkih rezervi, jer njihova praktična znanja mogu biti kvalitetna osnova za dalje praćenje ove problematike. Sugestije o postojećem stanju i pravcima korekcije obračuna tehničkih rezervi, koje su pratile odgovore na pitanja iz Upitnika ukazuju na otkriveni nedostatak postojeće regulative, i neophodnost donošenja detaljnijeg pravilnika i primerenijeg modela obračuna TR, uz ublažavanje rigidnosti lokalnih propisa u delu rezervacije šteta.

Komparativna analiza oba pravca istraživanja potvrdila je dopunsku hipotezu, jer najbolje metode, otkrivene u kvantitativnom istraživanju, nisu korišćene u aktuarskoj praksi Republike Srbije. Sugestije praktičara u vezi sa o postojećim stanjem i pravcima korigovanja obračuna tehničkih rezervi, ukazuju na nedostatak postojeće regulative i neophodnost etabliranja detaljnijeg pravilnika i boljeg modela obračuna TR.

Kvalitet ovog rada ogleda se u predstavljanju brojnih metoda za obračun rezervi za nastale neprijavljene štete, kao i primeni različitih metoda određivanja koeficijenta ostatka.

S obzirom na to da su sve projekcije izvršene samo na jednoj liniji poslovanja u jednom osiguravajućem društvu, dobijeni rezultati daju osnov i podsticaj sličnim empirijskim istraživanjima. To ujedno ukazuje i na pravce daljih istraživačkih napora. Namera da se na konkretnim, istorijskim rezultatima poslovanja, analizira adekvatnost primenjenih tehnika, kod svih neživotnih osiguravača, bila je onemogućena usled zaštite i poverljivosti njihovih podataka.

\section{REFERENCE}

Barnett, G., \& Zehnwirth, B. (2000). Best estimates for reserves. Proceedings of the Casualty Actuarial Society, 87(167), Part 2, 245-321.

Boor, J. (2006). Estimating tail development factors: What to do when the triangle runs out. Casualty Actuarial Society Forum, Winter, 345-390.

Bühlmann, H. (1983). Estimation of IBNR reserves by the methods chain ladder, cape cod and complimentary loss ratio. International Summer School. Unpublished.

Casualty Actuarial Society (CAS). (2013). The estimation of loss development tail factors: A summary report. Tail Factor Working Party. 
Dahl, P. (2003). Introduction to Reserving. Retrieved November 10, 2017, from http://kurser.math.su.se/pluginfile.php/5901/ course/section/1369/dahl2011.pdf

England, P. D., \& Verrall, R. J. (2002). Stochastic Claims Reserving in General Insurance. British Actuarial Journal 8(3), 443-518. doi.org/10.1017/S1357321700003809

European Commission. (2002). Report of the working group on non-life technical provisions to the IC Solvency Subcommittee. Working paper, MARKT/2529/02. Retrieved November 10, 2017, from http://europa.eu.int/comm/ internal_market/insurance/solvency_en.htm

Faculty and Institute of Actuaries. (1997). Claims Reserving Manual. The Faculty and Institute of Acturies.

Kočović, J., Mitrašević, M., Kočović, M. i Jovović, M. (2011). Problemi alokacije kapitala kompanija za neživotno osiguranje. Ekonomski horizonti, 13(2), 45-69.

KPMG. European Commission. (2002). Study into the methodologies to assess the overall financial position of an insurance undertaking from the perspective of prudential supervision.

Kremer, E. (1982). Credibility theory for some evolutionary models. Scandinavian Actuarial Journal, 3-4, 129-142. doi.org/ 10.1080/03461238.1982.10405260

Mack, Th. (2006). Parameter estimation for Bornhuetter/ Ferguson. Casualty Actuarial Society Forum, Fall 2006, 141157.

Mack, Th. (2008). The prediction error of Bornhuetter/ Ferguson. ASTIN Bulletin: The Journal of the IAA, 38(1), 87103. doi.org/10.1017/S0515036100015075

Mack, Th., \& Venter, G. (2000). A Comparation of stochastic models thah reproduce chain ladder reserve estimates. Insurance: Mathematics and Economics, 26(1), 101-107. doi. org/10.1016/S0167-6687(99)00039-6

Manghetti, G. (2000). Report: Technical provisions in nonlife insurance. Paper presented at the conference of the Insurance Supervisory Authorities of the Member States of the European Union.

Martinez-Miranda, M. D., Nielsen, J. P., \& Verrall, R. (2013). Double chain ladder and Bornhuetter-Ferguson. North American Actuarial Journal, 17(2), 101-113. doi.org/10.1080/10 920277.2013.793158
McClenahan, C. L. (1975). A Mathematical Model for Loss Reserve Analysis. Proceedings of the Casualty Actuarial Society, 62, 134-153.

Müller, H. (1997). Report: Solvency of insurance undertakings. Paper presented at the conference of the Insurance Supervisory Authorities of the Member States of the European Union.

Narayan, P., \& Warthen, T. V. (1997). A comparative study of the performance of loss reserving methods through simulation. Casualty Actuarial Society Forum, Summer 1997, vol 1, 175-196.

Obradovic, V. (2014). Inconsistent application of international financial reporting standards. Economic horizons, 16(3), 231243, doi: 10.5937/ekonhor14032390

Renshaw, A. E., \& Verrall, R. J. (1998). A stochastic model underlying the chain-ladder technique. British Actuarial Journal, 4(4), 903-923. doi.org/10.1017/S1357321700000222

Saluz, A., Gisler, A., \& Wüthrich, M. (2011). Development pattern and prediction error for the stochastic bornhuetterferguson claims reserving method. ASTIN Bulletin: The Journal of the IAA, 41(2), 279-313. doi:10.2143/AST.41.2.2136979

Schmidt, K. D. (2006). Methods and Models of Loss Reserving Based on Run-off Triangles: A Unifying Survey. Casualty Actuarial Society Forum, Fall 2006, 269-317.

Schmidt, K. D. (2008, July 14-16). Bornhuetter-Ferguson as a general principle of loss reserving. Paper presented at the ASTIN Conference, Manchester.

Schmidt, K. D. (2011). A bibliography on loss reserving. Technische Universität Dresden.

Schmidt, K. D., \& Schnaus, A. (1996). An extension of Mack's model for the chain-ladder method. ASTIN Bulletin: The Journal of the IAA, 26(2), 247-262. doi.org/10.2143/ AST.26.2.563223

Sherman, R. E., \& Diss, G. (2005). Estimating the Workers Compensation Tail. Casualty Actuarial Society Forum, Fall 2004.

Stanard, J. N. (1985). A simulation test of prediction errors of loss reserve estimation tehniqes. Proceedings of the Casualty Actuarial Society, 72, 124-153. 
Standard \& Poor's Ratings Services. (2008). Property/Casualty Insurance Criteria For Assessing Loss Reserve Adequacy For U. S. Based Insurers/Reinsurers. Retrieved November 11, 2014, from www.ratingsdirect.com

Taylor, G. C., \& Ashe, F. R. (1983). Second moments of estimates of outstanding claims. Journal of Econometrics, 23(1), 37-61. doi:10.1016/0304-4076(83)90074-X
Taylor, G. C. (2000). Loss Reserving: An Actuarial Perspective. New York, NY: Springer, doi:10.1007/978-1-4615-4583-5

Službeni glasnik RS. (2007a). Odluka o bližim kriterijumima $i$ načinu obračunavanja rezervisanih šteta. Beograd, Republika Srbija: Službeni glasnik RS, br. 86/2007.

Primljeno 7. novembra 2017, nakon revizije, prihvaćeno za publikovanje 22. decembra 2017. Elektronska verzija objavljena 29. decembra 2017.

Zlata Đurić je docent na Ekonomskom fakultetu Univerziteta u Kragujevcu, na nastavnim predmetima Osiguranje i Finansijska i aktuarska matematika. Doktorirala je na Ekonomskom fakultetu Univerziteta u Kragujevcu. Oblast njenog naučnoistraživačkog interesovanja je primena matematičke aparature $u$ finansijama i osiguranju.

Bojana Maračić je biznis analitičar u the Comtrade group, i ovlašćeni aktuar u osiguravajućem društvu Sogaz. Bavi se poslovima osiguranja. 


\title{
A COMPARATIVE ANALYSIS OF OUTSTANDING CLAIM RESERVES
}

\author{
Zlata Djuric ${ }^{1}$ and Bojana Maracic ${ }^{2}$ \\ ${ }^{1}$ Faculty of Economics, University of Kragujevac, Kragujevac, The Republic of Serbia \\ 2 Comtrade group
}

The key processes in the business of insurance companies which define the financial viability of their business activities, as the most important element, are the adequate amount of technical reserves. A qualitative assessment of the technical reserves level is the basic support to the management of the key business processes and proper strategic and financial decision-making in order to maximize the viability, profitability, competitiveness, and further development of the company. Based on the data on the operations of an insurance company, within a single line of insurance, different, in practice, most frequently used methods were applied in order to determine the deviation amplitude of the projected amounts from the actual claims. Another direction of research focuses on actuarial practice in non-life insurance companies operating in the territory of the Republic of Serbia. The comparative analysis of the obtained projection points to the fact that the chosen methods, commonly used in actuarial practice in the Republic of Serbia, should be monitored and reviewed. The results of the multidirectional research and detection of the existing problems provide a useful framework and a stimulating mechanism, as well as the guidelines to improve the operations and better positioning of insurance in the commercial and economic environment of the Republic of Serbia.

Keywords: technical reserves, outstanding claims reserves, chain indices, loss ratio

\author{
JEL Classification: G22
}

